\title{
EVOLUTION OF PERSIAN TRADITIONAL ARCHITECTURE THROUGH THE HISTORY
}

\author{
Mehrdad HEJAZI ${ }^{1}$, Bina HEJAZI ${ }^{2}$, Saba HEJAZI ${ }^{3}$ \\ ${ }^{1}$ Department of Civil Engineering, Faculty of Engineering, University of Isfahan, Hezar Jarib Street, \\ Isfahan, 8174673441 Iran (the Islamic Republic of) \\ ${ }^{2}$ Department of Architecture, Isfahan (Khorasgan) Branch, Islamic Azad University, \\ Isfahan, Iran (the Islamic Republic of) \\ ${ }^{3}$ Department of Architecture and Urbanism, Art University of Isfahan, Isfahan, Iran (the Islamic Republic of) \\ ${ }^{1}$ m.hejazi@eng.ui.ac.ir (correspondingauthor); ${ }^{2}$ bina.hejazi@yahoo.com ; ${ }^{3}$ saba.hejazi@yahoo.com
}

Received 11 February 2015; accepted 01 July 2015

\begin{abstract}
The architecture of Iran is wholly based on the comprehensive use of knowledge of both metaphysical and physical sciences. Architecture and structural engineering in Iran involve a great range of buildings distributed over a vast area from the borders of China to the Mediterranean coastlines. Certain design elements, developed by Iranian architecture and aesthetics, persisted for thousands of years and exerted a marked effect on other successive styles of construction throughout the world. Architecture in Iran solved complicated structural problems and created magnificent architectural masterpieces. In this paper, the evolution of Persian traditional architecture is discussed and a general overview of the paramount virtues of the traditional architecture and historical buildings of Iran with emphasis on structural and scientific features will be presented.
\end{abstract}

Keywords: Persian architecture; history; structure; construction material; dome; minaret; water-works.

\section{Introduction}

The name Iran, Land of the Aryans, derives from the people who immigrated to the Iranian plateau some 10,000 years ago (Pope 1965; Pope and Ackerman 1938), although human culture in this region has existed for 100,000 years (Carlton 1951). Ancient Iran, Persia, stretched over a vast part of the world from Northern Africa and Eastern Greece as far as Western China (Grant 1971) (Fig. 1). Today Iran extends from $25^{\circ}$ to $40^{\circ}$ North latitude and from $44^{\circ}$ to $63^{\circ}$ East longitude. It lies from the Caspian Sea in the north to the Persian Gulf in the south, and from Turkey and Iraq in the west to Afghanistan and Pakistan in the east. The total area of Iran is $1,650,000 \mathrm{~km}^{2}$. Iranian architectural tradition has played a fundamental and central role for 3,000 years during which time it had an ongoing relation with other cultures and traditions. Out of these processes, the art and science of construction developed and spread throughout a wide sector of the earth from the Far East to the Near East.
Building materials used in the constructions varied from stone, moulded mud, brick and wood as the load bearing elements to mortars and metal and wooden clamps for joints, waterproofing and reinforcing. All these were usually available in Persia and each type of material could be used in various applications and conditions, e.g. in the construction of underground cisterns to retain cool water and in the building of wind towers in the desert.

The architecture of Iran has been investigated in detail by many experts. Pope (1965), Pope and Ackerman (1938), who devoted their lifetime of research to the art of Persia, left an elaborate collection of information about Iranian architecture. Also Godard (1946, 1962) and Ghirshman (1951) and many others (Zander 1968) did a great job in proper study, restoration and maintenance of the historical monuments of Iran and partly disclosed the architectural aspects of the historical buildings. Despite the activity in architecture 


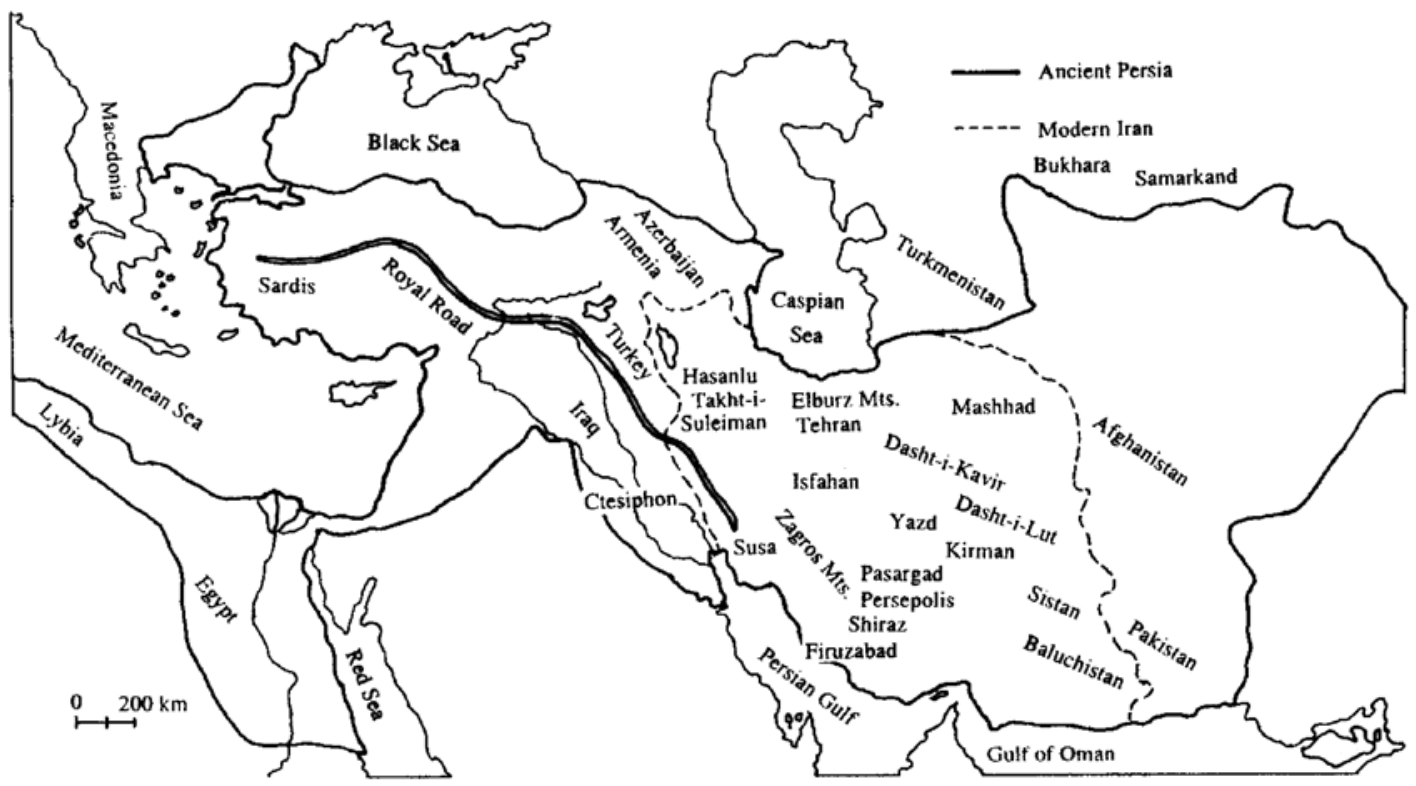

Fig. 1. The borders of ancient Persia and modern Iran. Source: Grant (1971)

during the twentieth century, no comprehensive effort had been made for the research of mechanical and structural characteristics and behaviour of historical buildings and structures of Iran until 1987. The only studies on this part were the work of Bybordi (1974) about the hydraulics of qanat, subterranean aqueducts, in 1974 and the study of Farshad (1977) on the shape of momentless tensionless masonry domes with a theoretical application on an existing historical dome in 1977. Hejazi (1987, 2005a, 2005b, 2006), Hejazi and Mirghaderi (1988, 1990, 2003), Hejazi et al. (2015) studied the detailed structural system and stability of a historical wooden structure. Zahraei (1989), Zahraei and Akbar (1190) investigated the structural systems of Iranian arches and domes. Hejazi (1990, 2003), Hejazi and Mirghaderi (1991), Hejazi et al. (2002) did a thorough study about the structural behaviour of Iranian historical domes that partly included Iranian minarets. He verified the stability of single-shell and stiffened double-shell domes subjected to various load conditions. Hejazi (Hejazi, Khallaghi 1994) investigated the history of water-works of Iran during the Islamic period in 1993. Alain Chassagnoux (1995a, 1995b, 1996a, 1996b, 1996c) carried out a comprehensive research into the evolution of techniques of vaulting in Persian architecture from the third to the seventeenth century A.D., in 1995. In 1997 the first comprehensive work on the structural concepts behind the architectural styles of Persian historical buildings was accomplished by Hejazi (1997).

In spite of deep metaphysical aspects, this important part of Iranian architecture, especially the pre-Is- lamic architecture, has been greatly ignored. The only dedicated works are those of Ardalan and Bakhtiar (1973) and Bakhtiar (1976) that express the mystic features of the architecture of Islamic Iran brilliantly, although there are some brief references in a few other sources (Burckhardt 1976; Nasr 1976, 1987).

All these studies indicate that the art and science of structural engineering within Iranian traditional construction has been something perfect and a result of the profound knowledge of the engineers and builders. The whole architecture of Iran supports this idea that ars sine scientia nihil.

Traditional construction in Iran includes many types of structures. Iranian construction varies from subterranean aqueducts, cisterns, wells, conduits, sewers and siphons to irrigation systems, canals, bridges, dikes, dams, water tanks, road networks; and from small huts and garden pavilions to some of the most beautiful and majestic buildings that the world has ever seen, such as huge wooden structures, masonry buildings, wind towers, minarets, vaults and domes. All its components are related and linked together to make a manifestation of a long lasting tradition. The engineers and builders not only mastered the most advanced structural skills, such as in the rotating building of the Takht-i-Suleiman (618 A.D.), the Throne of Solomon, which possibly provided the initial concept of the Castle of Holy Grail (Ackerman 1937; Christensen 1944; Matthews 1981; Pope 1965), but were also scholars of their era who activated the scientia sacra; one of these was Shaykh-Baha-al-Din-al-Amili (1546-1621 A.D.), the genius Safavid theologian, mathematician, 
architect, alchemist and poet, who solved the hydraulic problem of the division of the water of the ZayandehRud (the Life-Giving River) to supply the needs of both the agricultural fields and the city of Isfahan, Central Iran, and who also designed the mysterious heating system of the Shaykh-Bahai bath that heated the water and baffled the academic engineers and modern chemists until a few years ago.

Chief among Iranian architectural achievements, construction materials, some important historical buildings, town planning, road networks, water-works and aesthetic applications are explained through a chronological description of architectural styles. This originates a technical source of information providing a wide structural scope for further research into historical buildings of Iran; and initiates an important field for comparative study of other traditional buildings such as in ancient Egypt, ancient Greece, South America and India to demonstrate the transcendent unity of all traditional sciences in their very essence, but in different styles, times and places.

\section{Architecture and symbolism}

Architecture is the most transcendent type of art through which the Great Architect of the Universe manifests Himself to terrestrial humanity. It has a close relationship with cosmology and in each traditional civilisation represents the principles of the tradition. Although all traditions have the same Origin and lead to one Reality, they express that Essence in different ways.

By architecture civitas Dei descends midst the civitas mundi, and takes for example the name Naqsh-i-Jahan square, the Design of the Universe, a square in the city of Isfahan, half the world. Architecture is a reminder of the Divine Presence to traditional man in order to remember his original state in divinis; it is the aroma of what Plato calls $\alpha v \alpha \mu v \eta \sigma i \varsigma$, what permits man to have an intuition of where he comes from and where he is going to; it is the continuous attention; it is the beautiful letters of the Word. It is equilibrium in itself and creates harmony and beauty. It is the connection between the right and the left, the outward and the inward. Architecture is the messenger between the Creator and the created; it is sacred. It is the complex of most traditional sciences and technologies; therefore, the representation of Intelligence. It is the love of Wisdom.

Traditional architecture is an image of the cosmos, of man in his cosmic dimensions; and is a symbolic language, rich but simple, the voice in silence. Architecture aims at building a model of the Universe, coherently, to manifest its heavenly Ideas and provide a suitable place for the meeting of man and Logos. Architecture shows the whole creation. The main task of architecture is to project the Archetypes on to the earthly world. It is to create a square from that which is already a circle, then to remind the square the way of becoming the Circle. Architecture calls down the spirit to elevate the material; it is the key to the upper world for the lower one; it is the alchemisation of man.

The existing architecture of Iran essentially reflects two transcendent types of symbology, the pre-Islamic and the Islamic. Early pre-Islamic architecture is based on simplicity and the use of raw materials, mainly wood and unsawn stone, and uses the square as the main building plan. There is no need for detailed interpretation because man's mentality is the circle and in a closer relationship with the Origin. Earthly buildings are connected to heavenly Ideas with a simple style of expression; square is simply a direct reflection and clear symbol of the circle. Late pre-Islamic architecture gradually emphasises more emotional shapes from square to circle, using treated materials like brick, and balancing the motion of the mentality from energetic circle to concrete square. This facilitates the adoption of symbolic forms of Islamic architecture, of which Divine stability is symbolised by a cubic stone of meteoric origin worshipped in Mecca, and its Divinity is idealised by a spherical shape, the dome. The Islamic architecture of Iran relies on multiplicity to attract the attention of fragmented man, and on unity to orientate that attention towards the Divine Unity. In this style of architecture each building, a mosque or a house, is a sacratum in which the Divine Spirit dwells. Individual units are united in a complex all directed to the centre of the Universe, Mecca, the source of both multiplicity and Unity to and from the outer world.

In traditional civilisations all activities are correlated and considered as rituals, issuing from metaphysical principles. Having been related to Divine Intelligence, traditional art is wholly based on transcendent sciences. The noblest type of traditional art, i.e. architecture, is the most intelligible use of metaphysical knowledge in the material world. The elements of traditional architecture are designed by those who have already mastered metaphysical, and subsequently physical, sciences.

Symbolically, there are two ways of design, the right one and the wrong one. The whole architecture of all traditions in various times and different places shows the right way of design. This design originates in Divine Ideas and works with Universal Proportions to create a corresponding model. The Idea incorporates the model and causes it to resonate. The lower material receives the impressions from the upper spirit; the Sacred Dance is taking place here and now; this is the marriage of the active and the passive to produce the Perfect Man, the 
microcosm, the mirror of Logos. The twelfth-century A.D. mystic poet Nizami Ganjavi (The Haft Paikar 1924) told much in the building of the seven domes, planned on seven heavenly planets in seven different colours for the spiritual enlightenment of man: "I [Shideh, the builder] have ornamented this complex with seven brides/so that if the brides of the sky look at them/each from the above will assist one below through analogy and harmony [medius fidius]." If there is not a true knowledge in design the Idea will not participate in the material model. There is absolutely no eligibility for the wrong design. "He who has no understanding of this reminiscent Picture, all his portraiture is illegitimate even if he is the great portraitist of China," wrote the poet Hafiz (Poems for the Devan of Hafiz 1897) in the fourteenth century A.D.

Structurally speaking, in traditional architecture harmony and equilibrium between architecture and nature, and therefore permanence, are the main principles of design. Architecture functions in conformity with nature, such as nature does with the supra-mundane. The law for right design is the harmonic interrelation between things, as Rumi (The Mathnawi of Jalal u'ddin Rumi 1937-40) the great master and Sufi poet said in the thirteenth century A.D., "The harmony between opposites is the principle of this world." Architectural buildings are never in defiance of natural phenomena such as wind, temperature and earthquake. The role of structural elements is to make us of, not to resist, natural forces such as light, heat, wind and water; and correlation parameters on a proportional scale, not large safety factors, are chosen in design.

\section{Construction materials}

The use of materials in buildings is a work of spirit to impose the celestial form upon matter. Matter is the passive complement of Intelligence and would not become activated in material world without Logos. Matter is the mirror of Logos; therefore, there must be a coherence between the chosen material and the Idea it represents. The use of material, such as in buildings, is not an arbitrary matter, but absolutely consistent with Universal Law and the subject to be formed.

Stone was one of the first building materials, used in the foundation of some buildings in Northern Iran 7,000 years ago (Hodges 1970). The availability of clay promoted the use of amorphous mud and later sundried moulded mud in the sixth millennium B.C. (Ghirshman 1951; Pope 1965). In the meantime, the masons realised that mud brick shrinks and cracks; therefore, they used straw and shavings to strengthen the mud brick and thus for the first time initiated the use of composite materials in buildings. This can also be considered as the first step to reinforced materials, such as reinforced concrete, in which the fibrous component carries the tensile load (Farshad 1978). The rectangular flat-sided brick, made in a mould, was used by Iranians in the fourth millennium B.C (Fig. 2).

Limestone was used in Achaemenid monuments (560-330 B.C.), and during the Seleucids (330-250 B.C.), Parthians (250 B.C. -224 A.D.) and Sassanians (224-642 A.D.) rubble set in mortar became general. Since the Sassanians, brick gradually became the main construction material in Iranian buildings and it permitted the conformity of structure with new adopted forms, recalling that Iranian structural forms are of great variety and centralised by the arch.

The application of gypsum and lime mortars in buildings dates back to the first period of construction in Iran; nevertheless, the former was employed increasingly since the Parthians and the lime mortar became more current with the Sassanians (Wullf 1966). Ancient Iranians made hydraulic lime by mixing marl and clay that was used in inshore buildings, e.g. along the northern coastlines of the Persian Gulf (Farshad 1978). The hydraulic lime, which can also be considered as cement, is still in use for water structures like cisterns. Saruj, a waterproof mortar invented by Iranians that is composed of slaked lime, clay and rice chaff or volcanic ash, was applied to water tanks and cisterns. Iron and bronze clamps set in lead were used to bind the blocks of some buildings like at Pasargadae (550 B.C.), Susa (521 B.C.) and Persepolis (518-330 B.C.).

Wood is another material used in the buildings. The wood of cedar, which is hard with a high modulus of elasticity and sweet smelling thus preventing termites, made up the roofs of large rooms at Susa (1000 B.C.) and Persepolis and the beams and columns of other palaces. Oak, to a lesser extent, could be found in Persepolis. The wood of the plane-tree came into a wide use in the sixteenth and seventeenth centuries A.D. when the majestic wooden structures of the Ali Qapu and the Chehel Sutun were erected. Since the Sassanians, wood functioned as bracing for arched vaults to neutralise the arch thrust, and as framing for the buildings.

Buildings with metal skeletons were built in Aden during the Sassanians (Farshad 1978; Ibn-al-Balkhi 1912).
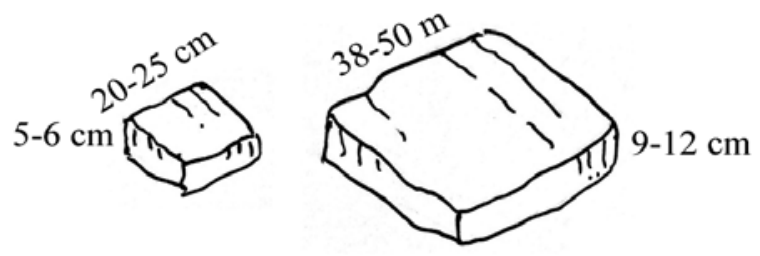

Fig. 2. Sun-dried bricks, Sialk, fourth millennium B.C. 
First phases of architecture and building (until 560 B.C.)

The history of the earliest discovered aspects of building in Iran, mostly in the western part, includes small houses with stone foundations, walls and floors dating from 8000-6000 B.C., remains of large houses built of handmade brick of mud at Ali Kosh in Western Iran dating from circa 6200-5800 B.C., and huts made of tree branches or handmade mud brick at Sialk in Central Iran in the fifth millennium B.C.

According to the seal shown in Figure 3, as Farshad and Isfahanian (1978) suggest, Iranians introduced the truss structures in the third millennium B.C. The triangular configuration of the truss, the connections of the elements at joints and the proportions make a perfect mechanical system. The Figure also shows the use of cylindrical silo bunkers with semi-dome roofs, i.e. shell type structures.

In the same era, vault construction was in practice. One of the oldest Iranian great monuments, using arched vaults, is the Choga Zambil ziggurat near Susa, the Elamite capital (the third millennium B.C.), built about 1250 B.C. (Fig. 4). This building comprises five separately built concentric square towers of different heights. The innermost tower was $35 \mathrm{~m}$ square at its base and $53 \mathrm{~m}$ high, half of the outermost base, with tombs, tunnels, arches, staircases and drains. In fact, ziggurats evoke the concept of mountains which have been of great significance since ancient times. In Elamite architecture unfired brick was used and temples were built on large square or rectangular shaped platforms as the foundation for sanctuary with a wooden roof on brick columns. In some buildings at Susa the vaults were 5 to $8 \mathrm{~m}$ across.

By the ninth and eighth centuries B.C. a highly developed architecture of stone and brick was elaborated in the north-west. Buildings were made of wood in a square plan and sometimes with tower-like multi-storeys. Temples were gabled with columns making a portico. Double and triple stone walls, with a thickness of

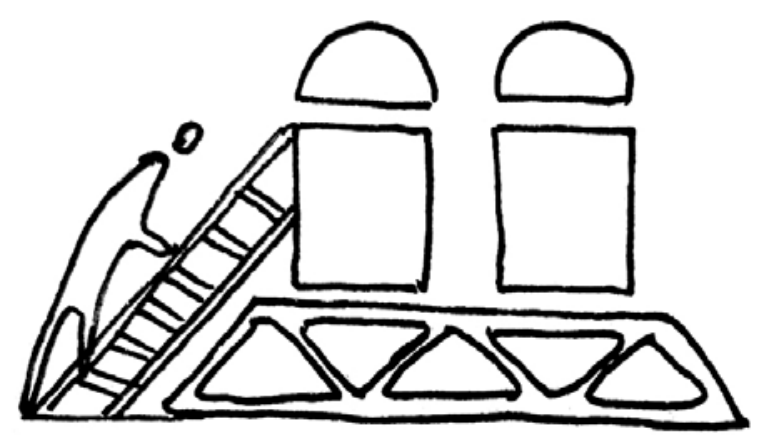

Fig. 3. Susa seal, showing the first datable application of truss structure, third millennium B.C.

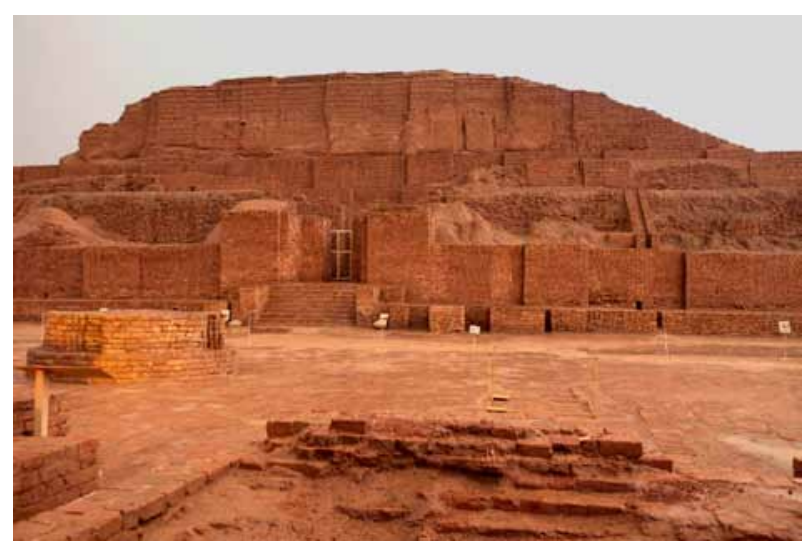

a)

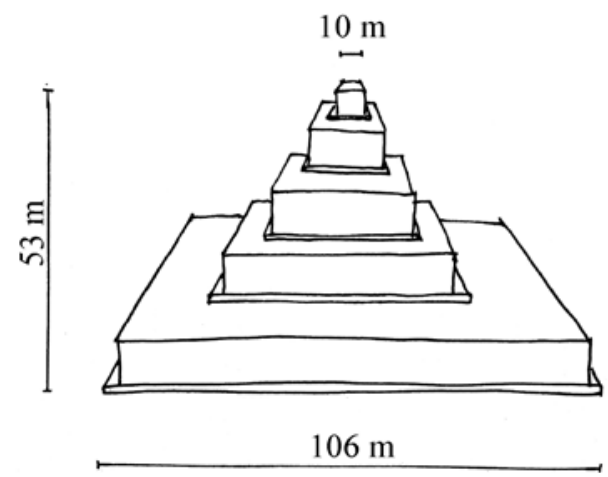

b)

Fig. 4. (a) The Choga Zambil ziggurat; (b) dimensions, near Susa, circa 1250 B.C.

$3.6 \mathrm{~m}$ and a height of $12 \mathrm{~m}$, surrounded some cities. The construction of city walls, which became more current in later times, had a symbolic reason for preventing the evil forces from gradually penetrating material mischief into the spiritual state.

\section{Stone basements and columns, majestic complexes (560-330 B.C.)}

In 560 B.C. Persia encompassed the whole of Western Asia. The main architectural and structural characteristic of Achaemenid architecture, which is reflected in Pasargadae, Susa and Persepolis, is the use of a huge platform as the substructure and numerous tall stone or wooden columns supporting the wooden roof.

Persepolis, one of the wonders of the world, was founded against a mountain on a platform of $275 \mathrm{~m}$ by 460 $\mathrm{m}$, surrounded by a retaining wall of 12 to $18 \mathrm{~m}$ high made of masonry blocks (Fig. 5). Blocks were bound with iron clamps without mortar and some were $15 \mathrm{~m}$ long and weighed 30 tonnes. In comparison with the Egyptian and Babylonian monuments, the columns in Persepolis were more slender and placed further apart whilst bearing the same load (Godard 1962). For example, the roof of the Apadana (A on the plan in Fig, 5b), 
$60 \mathrm{~m}$ square, was supported by 36 columns. These columns, each $10 \mathrm{~m}$ apart, were $18 \mathrm{~m}$ high, $2 \mathrm{~m}$ thick and elegantly tapered. The columns were crowned with capitals and the beams of the roof were placed in the capitals. By this means the conjunctions of continuous beams with columns, at which the maximum negative bending moment occurs in beams, were stiffened. The whole system was then a perfect and stable framework (Fig. 6). The underground water supply system and drains were cut out of the solid rock before the construction of top structure. Although the construction of Persepolis continued for more than a hundred years over an area covering $120,000 \mathrm{~m}^{2}$, a powerful management through successive generations skilfully directed the phases of the project and strictly maintained a uniform axis throughout, based on the original plan. Geometrical analysis shows that a complete knowledge of the Golden Proportion, the unique proportion of two terms when the ratio of the larger term to the smaller term is in the same way as the smaller plus larger to the larger, designated by $\varphi=(\sqrt{5}+10) / 2=1.6180339 \ldots$, is applied in the plan of Persepolis as shown in Figure 5.

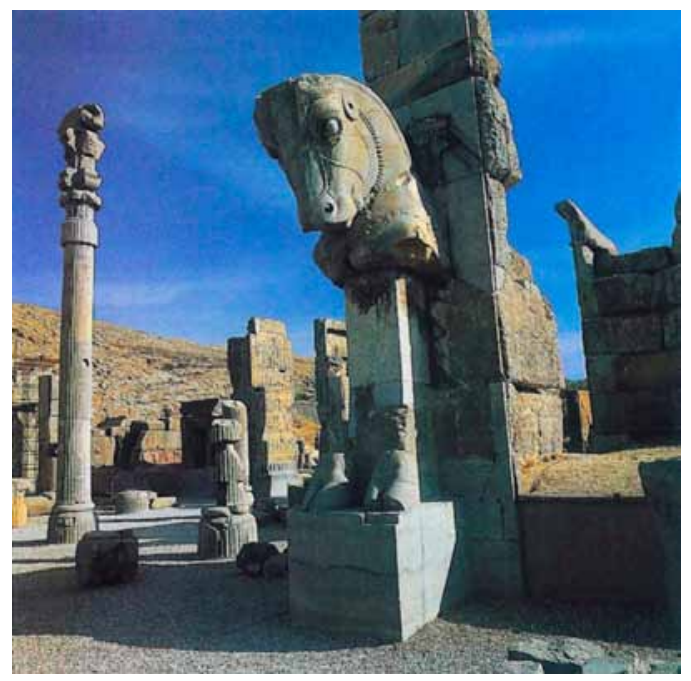

a)

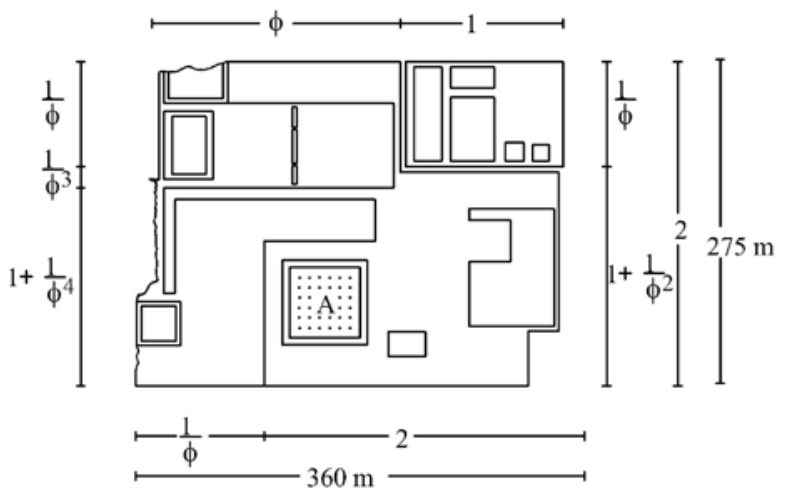

b)

Fig. 5. (a) Persepolis; (b) the use of the Golden Proportion in the Plan, Shiraz, 518-330 B.C.

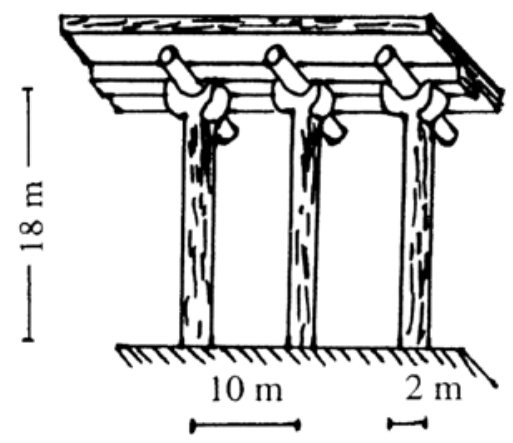

Fig. 6. Framework, stiffening of beam sections by using column capitals at the location of maximum negative bending moment, Persepolis, Shiraz, 518-330 A.D.

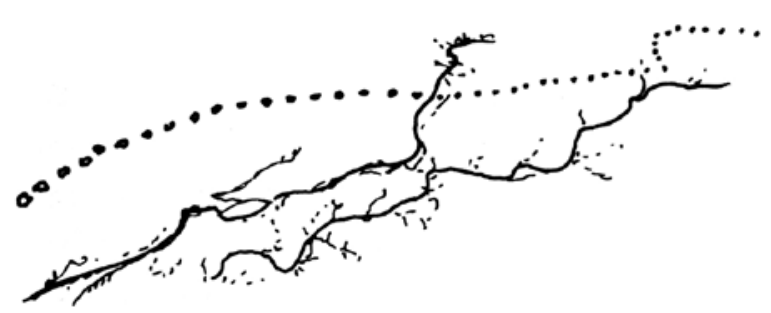

a)

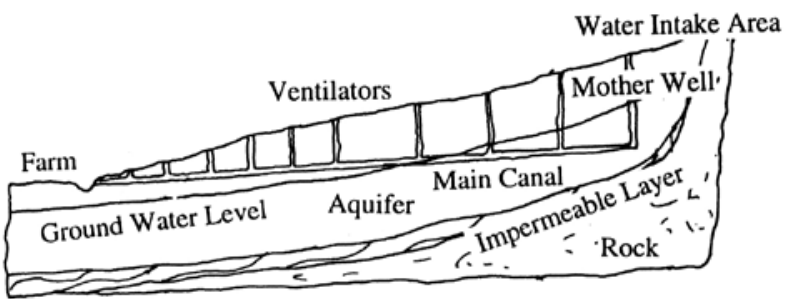

b)
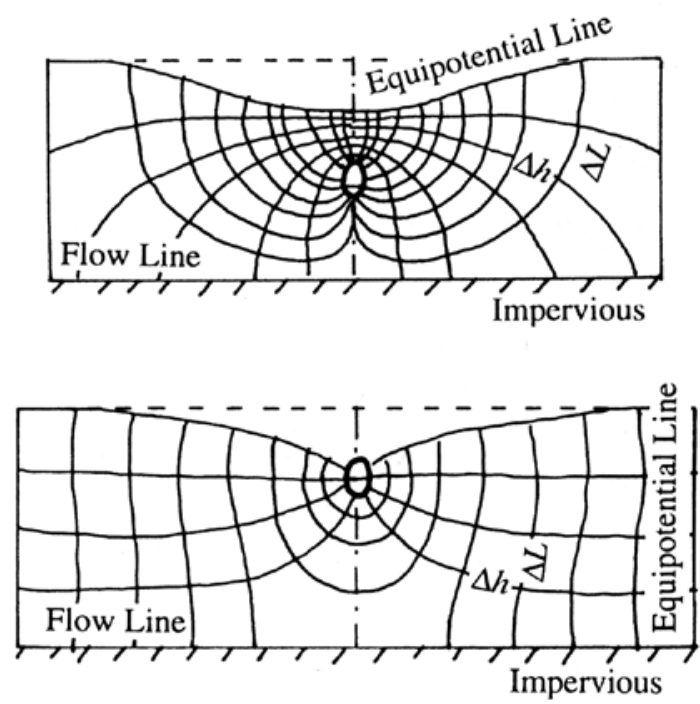

c)

Fig. 7. Qanat system: (a) line of shafts and rivers; (b) longitudinal section (source: Bybordi 1974); (c) cross-section when ground water is higher than or along the length of drain (source: Behnia 1987) 
One of the most important roads of the world history, called the Royal Road by Herodotus (1996), was constructed in that period. This stretch of $2,600 \mathrm{~km}$ led from Sardis (Western Anatolia) to Susa via Nineveh (Iraq, Fig. 1).

As water was sacred in the ancient Persia, a major part of construction works dealt with it. Iranians invented the qanat system about 1000 B.C., which brings water from mountainous regions through underground canals into towns (Behnia 1987, Bybordi 1974, Chassagnoux 1996a, Forbes 1964). Structurally a qanat system consists of a main underground canal, with a length of from several hundred metres to possibly $70 \mathrm{~km}$ and a slope of $0.1 \%$ more and with an elliptical cross-section of at least $1.2 \mathrm{~m}$ high and $0.8 \mathrm{~m}$ wide, a head well in the water intake area, many vertical ventilators or access shafts or wells, 30 to $100 \mathrm{~m}$ apart and 0.75 to $1 \mathrm{~m}$ wide, and the outlet (Fig. 7). These qanats have been used to provide for one-third to one-half of all the irrigation water in the country. Qanat is a masterpiece of applied hydraulics engineering. In ancient Persia siphons were used in high lands for supplying water by open canals.

\section{Dome on squinches, vaulted structures (330 B.C.-224 A.D.)}

During the Seleucids (330-250 B.C.) Hellenic forms became dominant for a few decades but were never absorbed. In North-east Persia from 174 B.C. (the first known Parthian architectural buildings) the Parthians developed a quite different architecture combining Greek and Persian elements. Dealing with the vault that is of most importance spiritually and is fundamental to the architecture of Persia, Parthian architecture brought about two architectural forms which had an everlasting influence on the architecture of the world. One was placing a dome on squinches and the other was the vaulted ivan (a portal or hall, which is enclosed only on three sides, with a certain depth, and roofed) structure (Fig. 8).

Putting a dome on a square plan is the transition from square to circle. The first solution was proposed by Persian engineers who invented a transitional section by building an arch, squinch, on each corner, transforming the square to an octagon. Then a further ring of smaller squinches was placed to reduce it to 16 sides which is close to a circle.

Parthian ivans roofed with high barrel vaults developed into the great ivan-entrances of the Islamic epoch. It was the square vaulted chamber of the Parthians which later in Sassanian and Islamic times became the square domed chamber so essential to the architecture of Iran and the world.

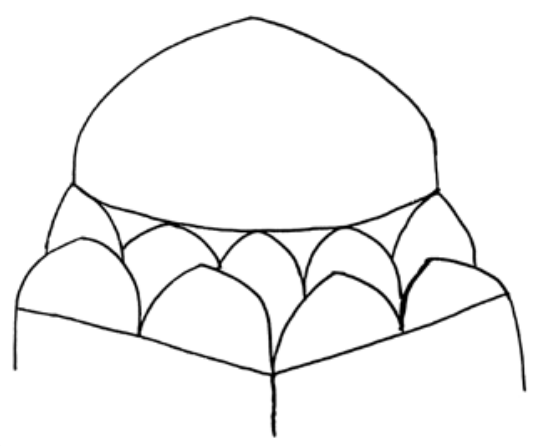

a)

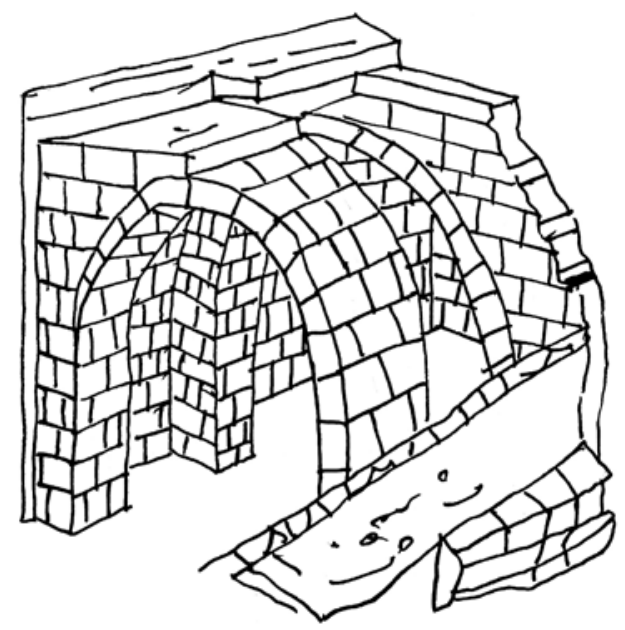

b)

Fig. 8. (a) Iranian dome on squinches; (b) vaulted ivan structure

\section{Transverse arch and vault, base isolation (224-642 A.D.)}

In the next era from 224 to 642 A.D., the Sassanians developed the dome and its setting on squinches. Huge vaults were built without centring. Massive weights were divided into structural elements. Loads were concentrated on separate supports.

The transverse arch and vault was one of the most important inventions in the architecture of the world that was invented by Sassanians to solve the structural problem of making window holes in the walls supporting a barrel vault; the earliest example is the Ivan-i-Kharkah in South-west Iran. Structurally, the barrel vault imposes a distributed line of thrust along the supporting walls. The walls must be sufficiently massive to support the vertical thrust of the vault. Considering the wall under thrust as a plane stress problem, it is not easy to pierce the walls with large windows without weakening the structure due to the concentration of stress near the window holes. Finite element analysis of such a problem shows that deep cracks occur at the top and bottom of the windows due to high values of tensile stresses at this 
region and insufficient tensile strength of masonry materials. This problem had made inside the vaults dark. The horizontal thrust of the vault requires the use of horizontal supports to prevent the out-of-plane displacement of the walls; hence, to prevent cracks resulting from increased spans (Fig. 9). This had made massive horizontal supports necessary. In the transverse arch and vault system, a number of strong arches and piers are erected within the fabric of the vault, which divide the barrel vault into a number of bays. The arches carry a larger proportion of the load than the barrel, and concentrate the vaulting forces; they act as a framework in the structure and increase the stability of the system. They also act as permanent formwork for the barrels, which can then be made bay by bay (Fig. 10). These vaults can be built for hundreds of metres, e.g. the seventeenth-century bazaars of Isfahan, Kashan and Shiraz, and may be pierced for large windows and gateways (Fig. 11).

In this era, the cross vault, that results from the intersection of two barrels, was favoured. Intersecting barrels may have different shapes, such as circular and pointed. The webs between the groins may have a single or double curvature. In cross vaults under weight load even very small displacements of the abutments may cause the vaults to crack (Fig. 12). Cracks may be bending tensile cracks, which are due to the eccentricity of the line of thrust and open only either at the extrados or at the intrados through which compressive forces are being carried, or they may be tensile cracks, which are due to tensile forces and extend through the entire

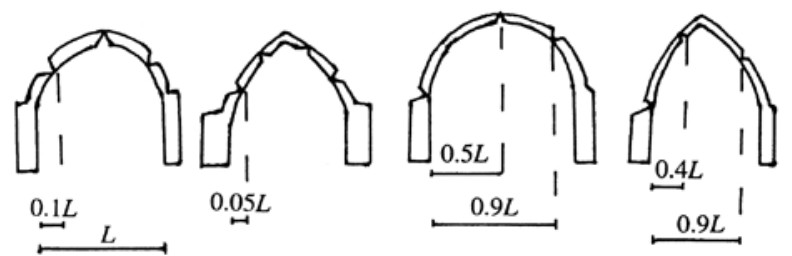

Fig. 9. Crack patterns resulting from increased spans: (a) circular arch, vertical load; (b) pointed arch, vertical load; (c) circular arch, horizontal load; (d) pointed arch, horizontal load. Source: Barthel (1989)

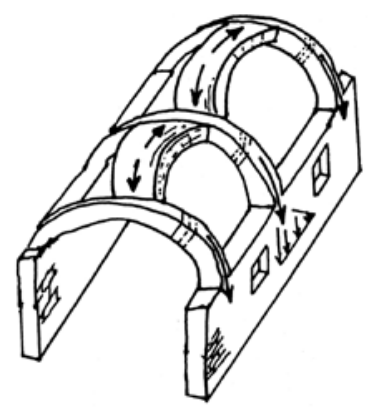

Fig. 10. Structural system of the transverse arch and vault. thickness of the webs across which no forces can be transmitted.

The earliest Iranian dome which is still in existence was built in Firuzabad, South-west Iran, at the beginning of this epoch. The diameter of this dome is $13.7 \mathrm{~m}$.

The widest unreinforced masonry (brick and gypsum mortar) vault without formwork in the world is the Sassanian monument Taq-i-Kisra at Ctesiphon, Iraq, built circa the second half of the third century A.D. Its ivan is $27 \mathrm{~m}$ high and $46 \mathrm{~m}$ deep. The vault that spans $23 \mathrm{~m}$ is sustained by walls of a thickness of $4 \mathrm{~m}$ at the top and $7 \mathrm{~m}$ at the base. The cross-section of the vault

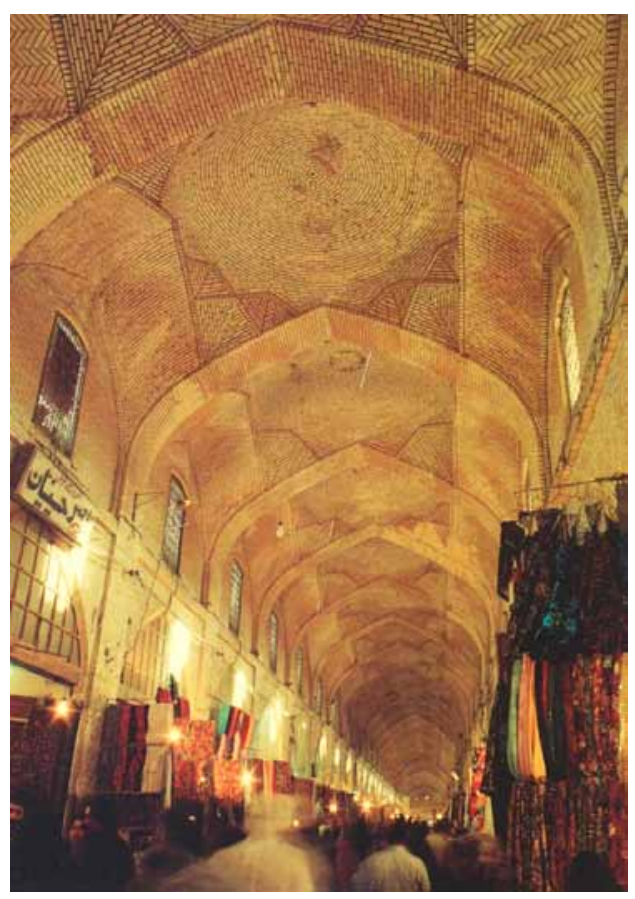

Fig. 11. Transverse arch and vault, Vakil bazaar, Shiraz, eighteenth century A.D.
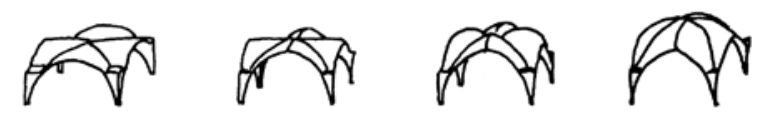

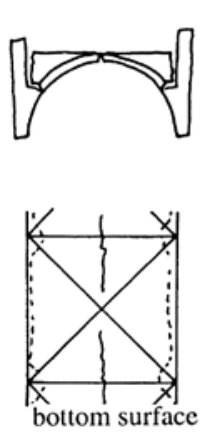

a)
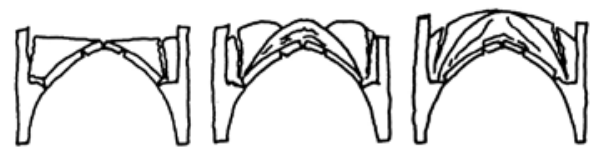

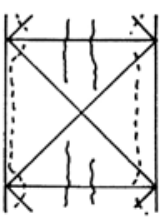

b)

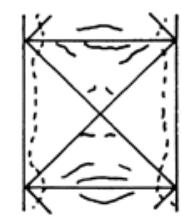

c)

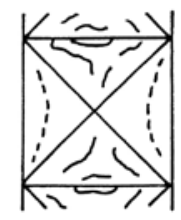

d
Fig. 12. Different types of cross vaults and crack patterns caused by spreading of the abutments. Source: Abruzzese et al. 1995 
has a parabolic shape that is one of the valuable inventions in vault construction.

The destroyed building of the Takht-i-Suleiman (or the Takht-i-Taqdis 618-28 A.D.), in the seismic part of North-west Iran, is significant in the history of Persian architecture (Fig. 13). This massive structure was set on rollers so that it could be rotated and it had machines for producing lightning, thunder and rain; the whole building was made to operate "in correspondence with the rotating sky" (Ackerman 1937; Christensen 1944; Pope 1965). This significant Persian masterpiece is probably the first known realisation of vibration isolation concept and it must have been a perfect earthquake dissipating structure.

The Izad-Khast dam near Isfahan was built in this era. The length of the dam is $65 \mathrm{~m}$ with a height of $6 \mathrm{~m}$. It is made of stone, gypsum mortar and saruj.

\section{Structures of exceeding beauty (624-1000 A.D.)}

The architecture of Islamic Persia (642 A.D.) preserved the essential elements of Sassanian architecture, which had used massive elements for structural stability, by developing it into lighter structural elements. The achievement was exceedingly beautiful, a more sensitive and more varied style of architecture that fulfilled new demands and continuously created buildings out of local materials, techniques and styles, but in the deepest kind of unity. The Islamic architecture of Iran achieved an individuality, and a superiority, distinct from that of Muslim countries. The most important emphasis of this architecture is on beauty, and the most fundamental element is the dome.

Dome is the finis bonorum. It is the Divinity whose mercy and compassion flows down to all levels of creation equally and asks the whole to return to the very centre of the Spherical surface, the Pole; to die from Being and to rise in rebirth in Beyond Being. The Pole is
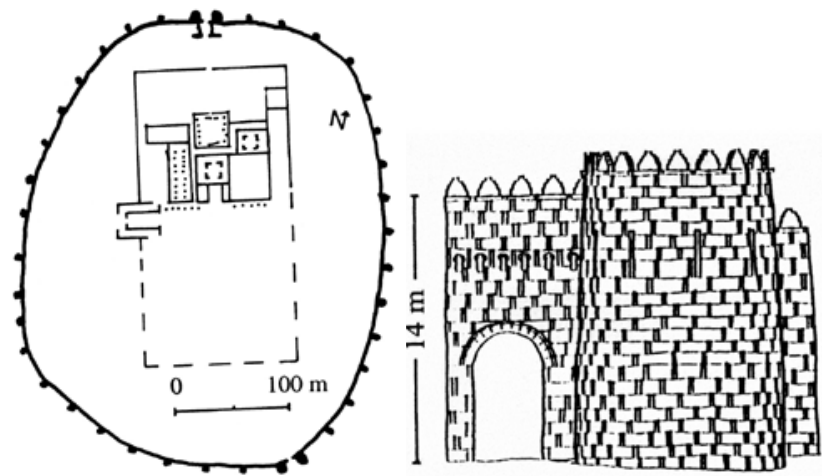

a)

b)

Fig. 13. Takht-i-Suleiman: (a) plan (source: Von der Osten, Naumann 1961); (b) south-east gate (source: Naumann in Pope and Ackerman 1938), 618-28 A.D. the only unpolarised point on the sphere. It polarises all the lower points and then attracts them to the Origin to give them freedom from polarisation; as if the Universe is nothing but the Divine polarising his unpolarisable essence. By dome man becomes the Word.

There are few buildings from the first two Islamic centuries remaining in Iran. The Masjid-i-Fahraj in Yazd (687 A.D.) is the oldest building. The slightly pointed arches in the Tari-Khana in Damghan (760 A.D.) are the first recorded in Persia.

In the ninth century A.D., a number of independent developments in architecture emerged; of the monuments still remaining, mosques and tombs predominate. In North-east Persia (Turkmenistan), the Samanids (892-999 A.D.), under whom a Persian renaissance began to take place, and then the Ghaznavids (962-1040 A.D.), created some important monuments. The tomb of Ismail Samanid (907 A.D.) in Bukhara (Turkmenistan), with the masterful use of brick that had no precedent, is an important building in the study of eastern Islamic architecture. It strongly influenced subsequent Islamic architecture, and it is one the masterpieces of Persian architecture. In this building, the rib in the squinch transfers the thrust of the dome downwards, something similar to a Gothic flying buttress. The Gunbad-i-Qabus (1006-7 A.D.), the tomb tower of Qabus in Gurgan, North-east Iran; with a height of $61 \mathrm{~m}$, of which $11 \mathrm{~m}$ is underground, it is one of the most incredible tombs in Persia and the earliest of some 50 towers still standing (Fig. 14).

Contemporary with the Ghaznavids, in Central and Southern Iran the Buyids (935-1055 A.D.) developed a different architectural pattern. Few Buyid monuments remain. They built splendid tomb towers, as at Rayy, close to Tehran, which are now only archaeological sites.

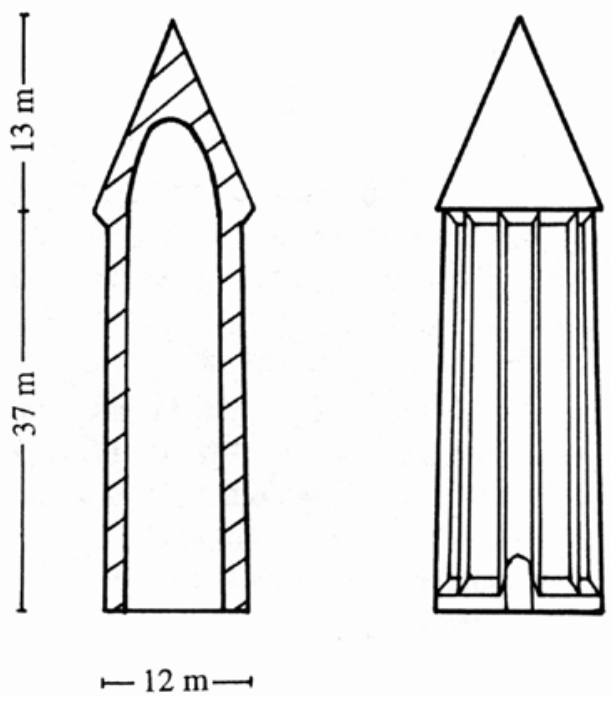

Fig. 14. Gunbad-i-Qabus, Gurgan, 1006-7 A.D. 


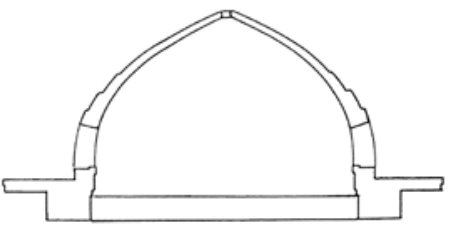

a)

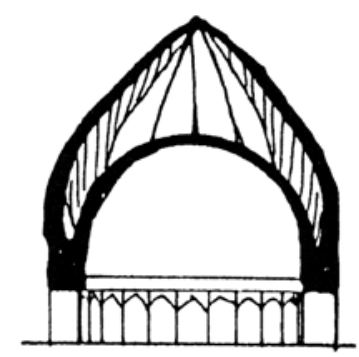

b)

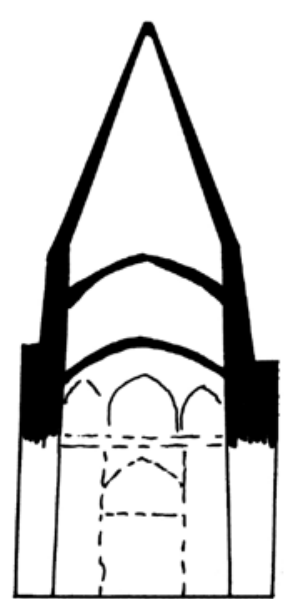

c)

Fig. 15. Three types of domes: (a) single-shell; (b) double-shell; (c) triple-shell.

\section{The perfect dome, the double-shell dome (1000-1157 A.D.)}

The culminating expression of a Persian renaissance that had begun in the second half of the ninth century A.D. was architecture, the contribution of the whole tradition and culture of Persia, that reached its apex during the Seljuks (1000-1157 A.D.), with one of the world's great architectural styles. Seljuk buildings reveal important improvements in vaulting and constructing domes. The first double-shell dome of the world was built in the eleventh century A.D., which later became a common practice in the thirteenth and fourteenth centuries A.D. (Fig. 15). Ribs were used to build wider vaults and taller minarets appeared. Construction of squinches as a zone of transition between square below and circle above flourished significantly. The finest use of brick and brick decoration, organised stucco designs and expressive colours characterised the architecture of this period.

The Masjid-i-Jami (the Jami mosque) of Isfahan, one of the greatest buildings in the world in Isfahan, exemplifies the nobility of Seljuk architecture and it includes more than 900 years of Persian architecture (Fig. 16). The building of a mosque expresses the cosmology of the religion. The dome, representing the Spirit and heavenly sky, encompasses the square basis, symbolising the world with the four elements, through an octagonal transition section, as eight angels supporting the Divine Throne. The building shows the equilibrium and reflection of Divine Unity in Universal Order. The whole complex indicates the Unity in its deepest form. The dome is the indivisible Unity and the polygonal sections correspond to Its attributes. If, as Pythagoras says, "all is arranged according to Number," and if there is an analogy between pure essences or archetypal Ideas and their perceivable reflections, there must exist exactly such a transcendent arrangement of numbers (or proportions) in the reflected image, i.e. in the dimensions of the building of a dome and its lower chamber. This happened in 1088 A.D. in the history of Islamic Persian architecture by constructing the Taj-alMulk dome, on the north side of the Masjid-i-Jami, that is a practice of perfectly right and strictly analogous design, a supernatural creation of human architecture.

The outer diameter of the dome is $11.7 \mathrm{~m}$. Its height from the base and ground levels is $6.3 \mathrm{~m}$ and $20 \mathrm{~m}$, respectively. The thickness of the dome shell varies from $0.36 \mathrm{~m}$ at the vertex to $0.66 \mathrm{~m}$ at the base. This is undoubtedly the most perfect dome known in the world. Theoretically it is proved that for weight loading the dimensions of the Taj-al-Mulk dome exactly match the formulae for the shape of the meridional curve and thickness variation of masonry domes without tensile stresses and bending forces (Farshad 1977). Using the finite element method it is possible to show that the resultant stresses due to the system of bending forces are negligible compared with the system of membrane forces not only for weight load but also for wind and temperature and more significantly for the dynamic

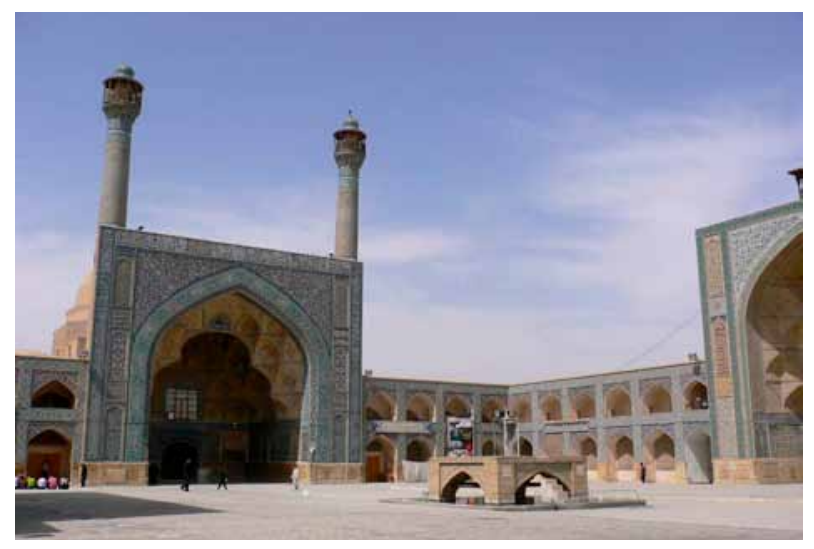

Fig. 16. Jami mosque in Isfahan, 900 years of Persian architecture. 


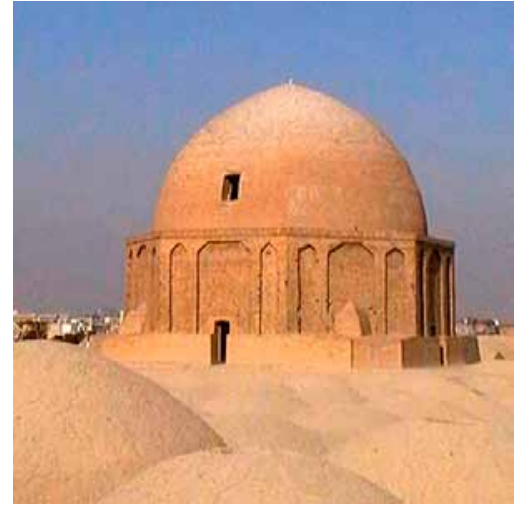

a)

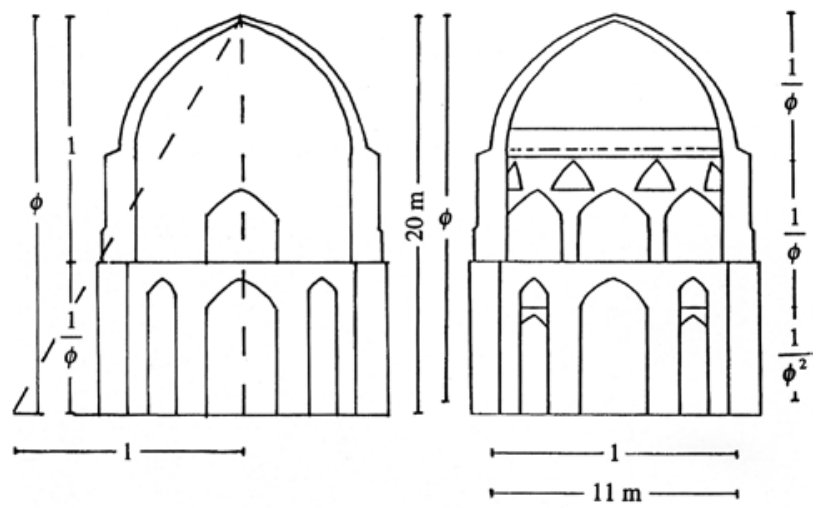

b)

c)

Fig. 17. (a) The Taj-al-Mulk dome and the Golden Proportion; (b) Schroeder's (source: Pope, Ackerman 1938) geometrical analysis; (c) Hejazi's suggestion, Isfahan, 1088 A.D.

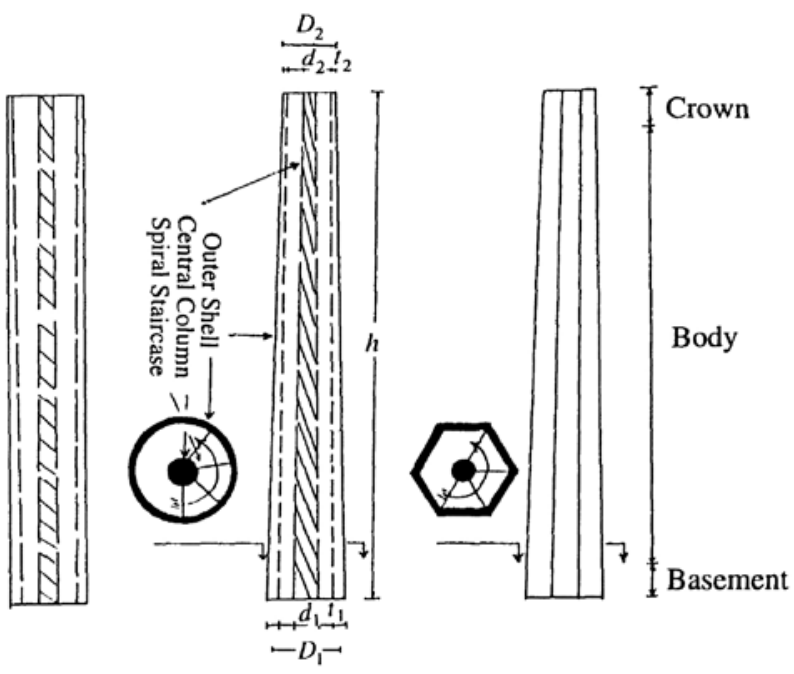

a)

b)

c)

Fig. 18. Three types of minarets: (a) cylindrical; (b) conical; (c) polygonal

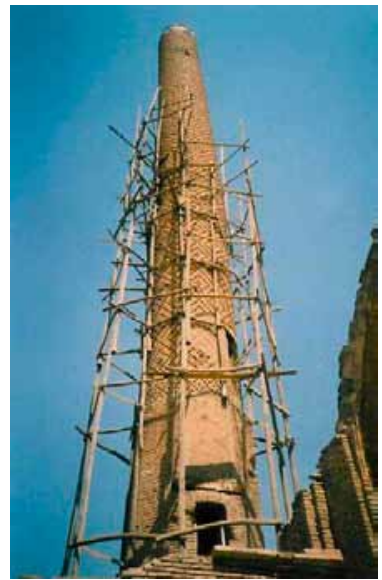

a)

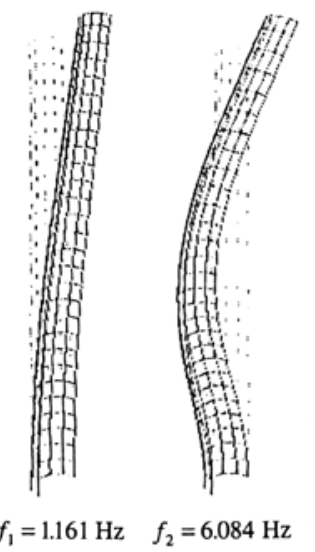

b) effects of earthquakes. Further, finite element analysis of the Taj-al-Mulk dome proves that if different shapes of cross-section, or different variation of meridional thickness, were used for the dome shell the magnitude of stresses and forces induced in the dome would increase and the design would not be perfect any more. This dome is the ultimate application of the theory of shell structures that has been unrivalled in the world for 900 years. Its harmonious and studied proportions rank it as an earthly idealisation of the domical Heaven. Geometrically, the dome and the chamber below show the sophisticated application of the Golden Proportion in the dimensions of the building (Fig. 17). The vertical cross-section of the building exactly matches the Golden Rectangle which in turn could be divided into further smaller Golden rectangles generating the Golden Spiral, symbolically the origin of Being. Its uniqueness and beauty are absolutely a matter of dimensions. This dome is the ideal dome.

Fig. 19. (a) Sin minaret; (b) mode shapes, near Isfahan, 1131 A.D. 
A large number of minarets were constructed during this period. A minaret is generally made up of three parts, basement, body and cowl or crown (Fig. 18). The shape of the body can be cylindrical, conical or prismatic. The body comprises the central column, the spiral staircase and the outer shell. Structural static and dynamic analysis of a number of minarets shows that they maintain their stability and strength against dead and wind loads, but some of them will collapse due to earthquake. In some minarets the spiral staircase increases the stiffness of the minaret structure against lateral loading (Fig. 19).

\section{Verticality, attenuation, magnificence (1218- 1334 A.D.)}

The architecture of the Il Khanids (1218-1334 A.D.) was a consistent development of Seljuk styles. Its apparent feature was a more immense scale. Structural elements were multiplied to fulfil different functions, solids were reduced and open space was increased. Structural problems were more successfully solved. Construction of transverse vaults was fully developed. Brick building styles reached the highest point. The verticality and attenuation of selected forms were favoured and were achieved in certain ways. A larger ratio of height to the interior width of the chamber was displayed. Higher and narrower ivans were crowned by a pair of tall minarets. The overall height of domical structures, as a result of the use of double-shell domes, was increased. Higher arches were used. Wall panels became tall in relation to their width. Angle colonnettes of slender proportions were frequently used. All the techniques of decoration and production of coloured tiles advanced.

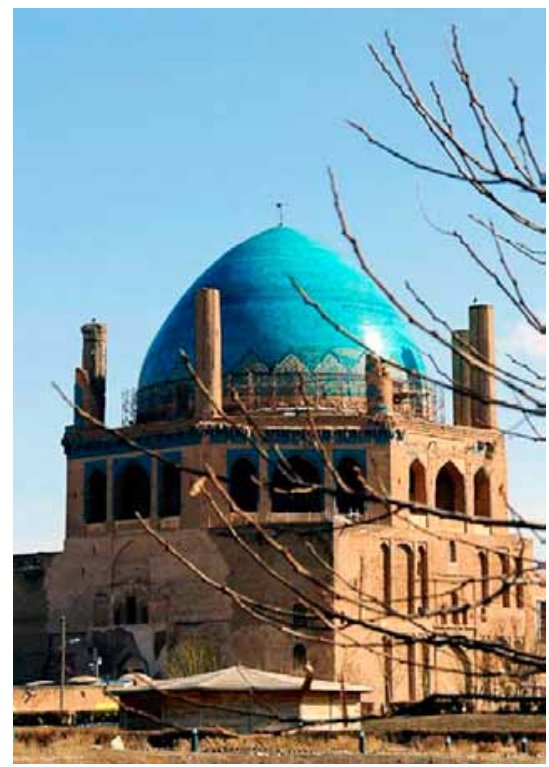

a)

Fig. 20. (a) The dome of the mausoleum of Uljaitu; (b) elevation, Sultaniya, 1305-13 A.D.
One of the greatest achievements of this period was the creation of Sham, a town near Tabriz in Northwest Iran at the beginning of the fourteenth century A.D., including madrassas (colleges), a philosophical academy, library, hospital, administrative palace and observatory. Its majesty, today only rubble, was unrivalled since Persepolis.

The double-shell dome of the mausoleum of Uljaitu in Sultaniya (1305-13 A.D.), $54 \mathrm{~m}$ high with a diameter of $24.5 \mathrm{~m}$, built in this period is the largest existing dome in Iran (Fig. 20). Its section is ovoid. The thickness of the dome shell varies from the base $(1.4 \mathrm{~m})$ to the apex by means of a series of steps. The inner and outer shells are respectively $0.6 \mathrm{~m}$ and $0.4 \mathrm{~m}$ thick near the base. The two shells are connected at certain points within the interdome. The weight of the dome is concentrated on a small number of supports, without the use of any shoulder or buttress. In a detailed study of the building in 1883, Dieulafoy (1883) found the use of geometry in the design of the interior and exterior elevations. The intersections of squares and equilateral triangles within a framework are the fixed points for measuring and planning the building. Therefore, the size of every section is in a calculated relation with every other section.

The Masjid-i-Jami in Tabriz, probably the most massive brick structure standing, was built in 1312-22 A.D. A vault of $30.5 \mathrm{~m}$ wide, $46 \mathrm{~m}$ high and $48 \mathrm{~m}$ deep covered the sanctuary ivan. The tremendous vault collapsed after it was built, but the building is still in use.

From the twelfth to the fourteenth centuries A.D. the skilfully planned walls of Yazd, Central Iran, were built.

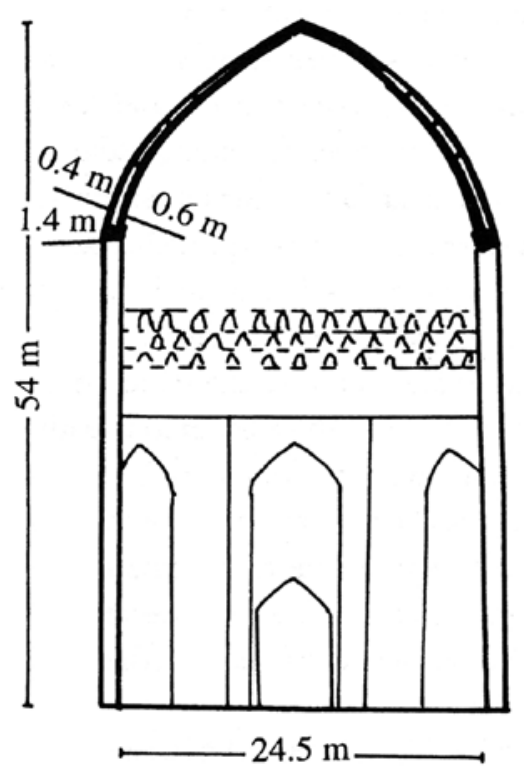

b) 


\section{Refinement (1314-1502 A.D.)}

Under the Muzaffarids (1314-93 A.D.) the concept of the superb overall tile mosaic pattern, such as in the Masjid-i-Jami in Kirman, appeared, which was assimilated in Southern Iran.

In the architecture of next period, the Timurids (1370-1502 A.D.), the structural skills of the Il Khanids continued coherently but with greater refinement. Total separation of the outer and inner domes was achieved, and higher drums, usually rose directly from the roof, were used. Portals were built very high and facades imposing. Soaring minarets appeared. Tile mosaic work reached its highest achievement.

One of the most important monuments erected during the entire period was the mosque of Gawhar Shad (1418 A.D.) in Mash had, North-east Iran. This building shows the most beautiful example of the use of colour in architecture. The mosque portal has an interesting feature with a pair of minarets extended to the ground, instead of surmounting the portal as had previously been the case in Iran.

The Gur-i-Amir (1404 A.D.), in Samarkand (Turkmenistan), is structurally an important monument. It has a double-shell dome, $37 \mathrm{~m}$ high with an interdome of $11 \mathrm{~m}$, set on an $8 \mathrm{~m}$ high cylindrical drum, which in turn rises out of a $13.5 \mathrm{~m}$ high octagonal chamber. A number of radial walls connect the two shells of the dome in the interdome (Fig. 21).

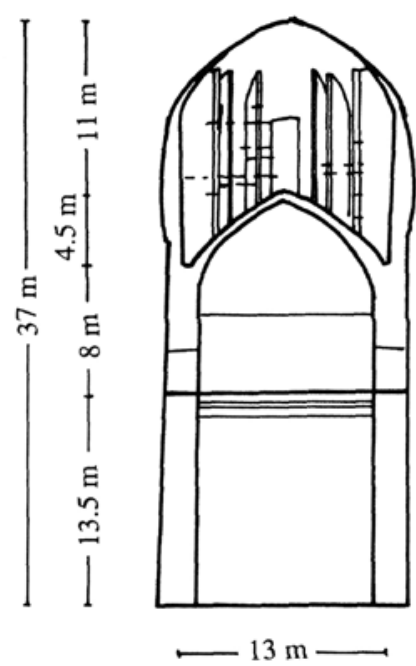

Fig. 21. Gur-i-Amir, Samarkand, Turkmenistan, 1440 A.D.

\section{Culmination, town planning, Isfahan (1491- 1722 A.D.)}

The architecture of the Safavids (1491-1722 A.D.), although not being the supreme period of Persian architecture, represents the culmination of Persian Islamic architecture. Printed tiles were introduced, and retaining the mosaic and glazed bricks, the richest possible combinations and imaginative details were created on a large scale.

The most elaborate architectural creation of this period was Isfahan (Fig. 22). In the seventeenth century A.D. Isfahan was one of the largest cities of the world, with so many new mosques, palaces, bridges, avenues and parks. It was referred to as Nisf-i-Jahan (half the world). In fact, Isfahan was designed not only to be half the world but also to manifest the beauty of the whole Universe. Isfahan was the final presence of the civitas $D e i$ in the midst of the civitas mundi in the traditional Middle East. Isfahan was civitas Dei in medio civitatis mundi.

Architecturally the seventeenth-century Isfahan was the ultimate application of town planning, road design, water-works, bridges, and structural and civil engineering. The great maydan (square) at Isfahan, the Maydan-i-Naqsh-i-Jahan or the Naqsh-i-Jahan (the Design of the Universe) square, is the centre of the city, which runs directly north-south and measures $500 \mathrm{~m}$ in length and $146 \mathrm{~m}$ in width, surrounded by two-storey arcades (Fig. 23).

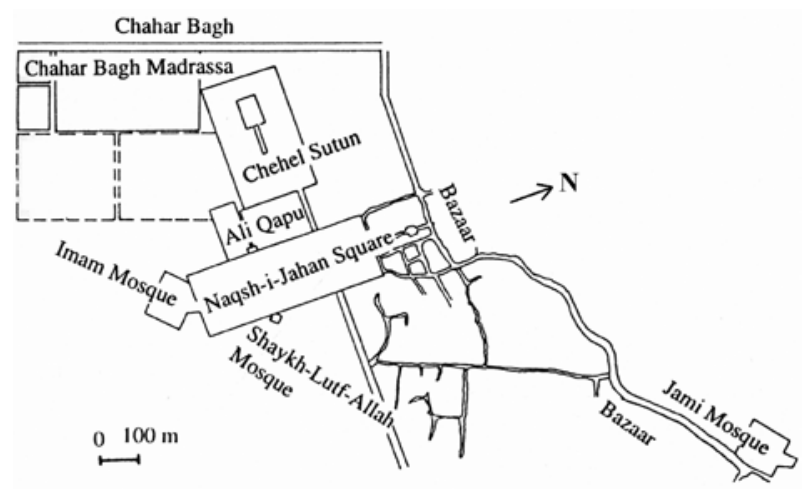

Fig. 22. Isfahan, civitas Dei in medio civitatis mundi

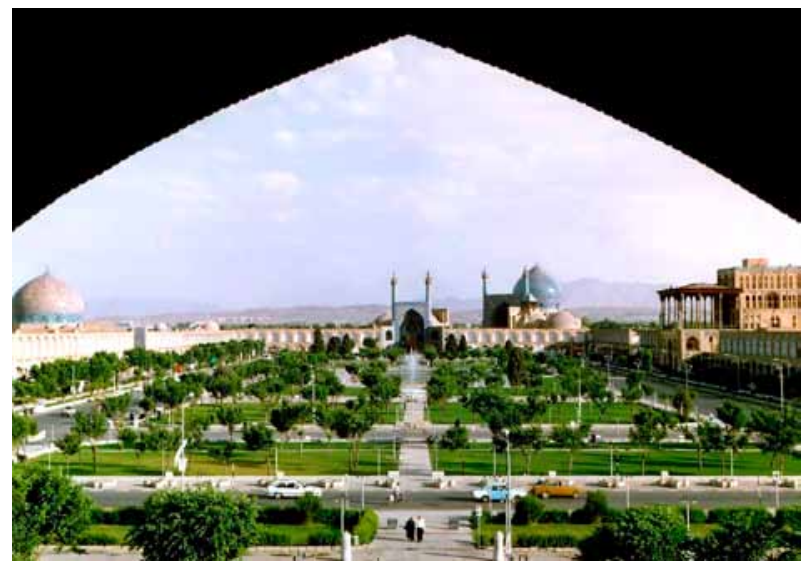

Fig. 23. Naqsh-i-Jahan (the design of the universe) square, view from the north, Isfahan 
Four main buildings face onto the maydan. On the southern side of the maydan is the Imam mosque (1612-38 A.D.). This building, with its beautiful dome and twin minarets and its imposing portal flanked by another pair of minarets, represents one of the world's greatest buildings and the culmination of a thousand years of mosque building in Persia. Opposite, at the northern end of the maydan, is the tiled gateway of the Qaysariyah, the handsome bazaar. At the middle of the eastern side, is the mosque of Shaykh-Luft-Allah (1601-28 A.D.), an excellent building with its exquisite dome ornamented with arabesques (Fig. 24). Facing it, across the maydan is the palace of Ali Qapu (1597-1668 A.D.), with a high columnar talar (porch) looked over the maydan.

The lofty double-shell brick dome of the Imam mosque is probably the most important Iranian stiffened double-shell dome. The outer diameter of the drum of the dome is $26.3 \mathrm{~m}$. The drum is $7 \mathrm{~m}$ high and 1.7 and $2.2 \mathrm{~m}$ thick at the base and the top, respectively. The heights of the upper and lower shells from the base level of the drum are respectively 24.45 and $13.2 \mathrm{~m}$ and the distance between the two shells (interdome) is $11.25 \mathrm{~m}$. The upper shell is $52 \mathrm{~m}$ high from the ground level. The thickness of the lower shell varies from 0.22 to $1.35 \mathrm{~m}$

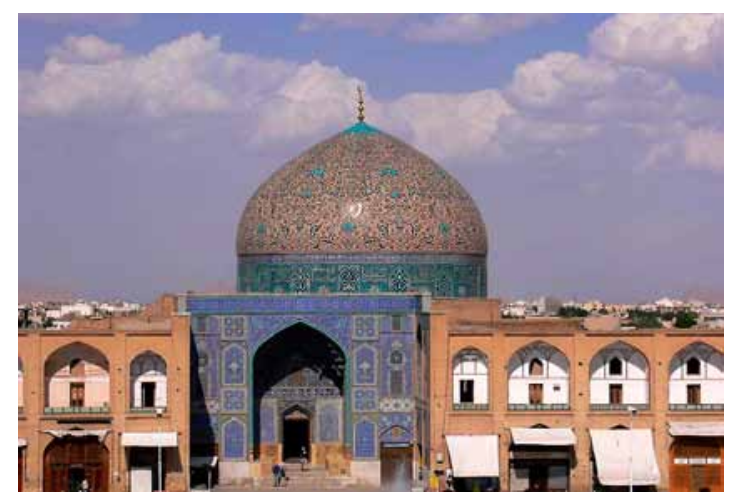

a)
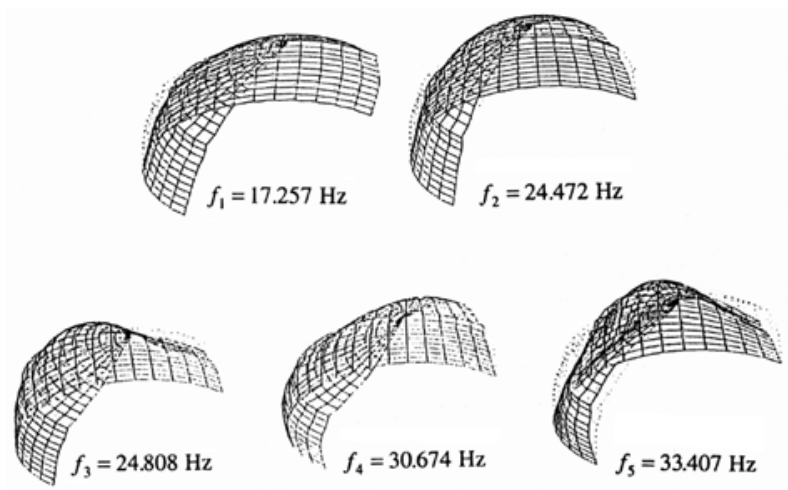

b)

Fig. 24. (a) Shaykh-Lutf-Allah dome; (b) mode shapes, Isfahan, 1601-28 A.D. towards the drum and the thickness variation of the upper shell is from 0.3 to $1.1 \mathrm{~m}$ towards the base. The upper shell is a turnip-like dome. There are 24 radial or meridional brick walls (stiffeners) in the interdome that are connected to the two shells. The thickness of the walls is $0.45 \mathrm{~m}$. The walls have three different heights. The long, intermediate and short stiffeners are respectively 12.6, 10.7 and $7.6 \mathrm{~m}$ high. These are set in groups of descending order, arranged at equal distances around the circumference (Fig. 25). In order to investigate the effect of each major structural element, i.e. the upper shell, the bottom shell and the meridional stiffeners, finite element analysis of the structure has been performed for different loads, such as weight, wind, temperature and earthquake. Numerical results from structural static and dynamic analysis of the dome prove the profound knowledge of the builders in the design of such a massive structure. The key element of the design is the use of stiffeners that are essential to make the dome structure stable and strong enough. The mosque is a wonder of acoustics, in which the sound is carried equally to all parts of the building, the dome chamber, the cloisters on each side and the courtyard. In particular, sound is reflected seven times in the centre of the dome chamber.

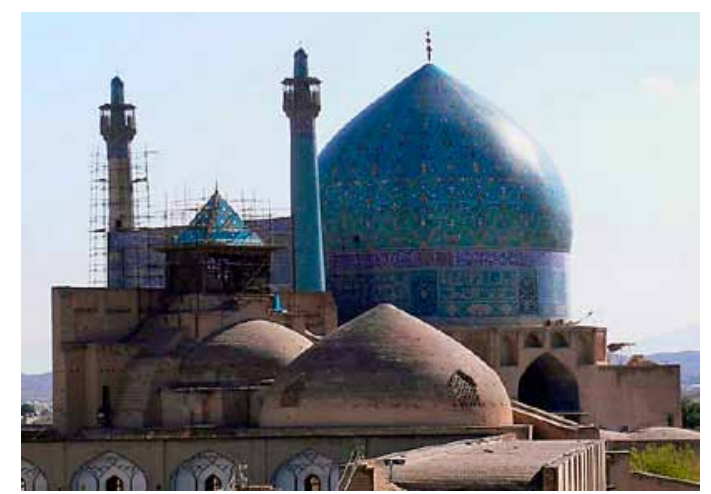

a)

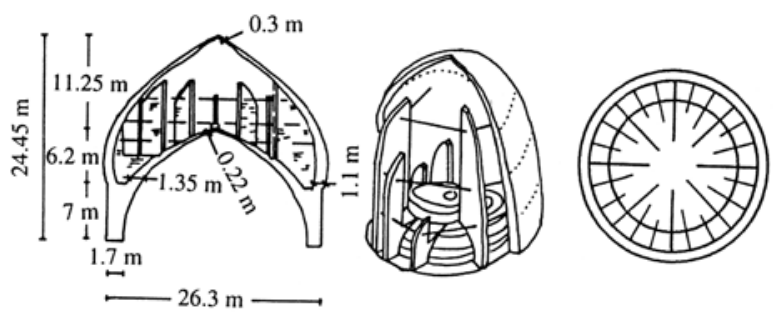

b)

Fig. 25. (a) The stiffened double-shell dome of the Imam mosque; (b) dimensions, Isfahan, 1612-38 A.D. 
Structural analysis of the Shaykh-Lutf-Allah dome, with a outer diameter of $20.8 \mathrm{~m}$ and heights of $12 \mathrm{~m}$ and $28.5 \mathrm{~m}$ from the base and ground levels, respectively, and a varying thickness from $1.3 \mathrm{~m}$ at the base to $0.95 \mathrm{~m}$ at the vertex, indicates that the resultant stresses do not exceed the allowable stresses in the dome subjected to different loads (Fig. 24).

The science of acoustics, which is a matter of mathematics, harmony and architecture, can also be investigated in the music and sound room of the seven-storey building of the Ali Qapu (1597-1668 A.D.), the High Gate or Sublime Door (Fig. 26). In the sound room on the sixth floor, hollow places in the walls, representing pots and vessels, probably retained the echoes and produced the sounds of music in all parts. The wooden part of the Ali Qapu that covers the eastern veranda of the building is an important structure in the architecture of Iran (Fig. 27 and Fig. 28). It is one of the earliest existing wooden buildings in its perfect form. It represents an advanced theory of structural timber in design of column, beam, truss and connection elements. The wooden structure comprises 18 columns with a height of $10.5 \mathrm{~m}$ and an octagonal shape of cross-section with a diameter of $0.5 \mathrm{~m}$ at the base decreasing to $0.3 \mathrm{~m}$ at the top. The columns that stand on a wooden spreader support 6 beams of $17.5 \mathrm{~m}$ long in one direction of which $1.2 \mathrm{~m}$ are inside the side wall. The cross-section of the beams is circular with a diameter of $0.4 \mathrm{~m}$ at the wall and $0.55 \mathrm{~m}$ at the other side. In the other direction, there are three lines of beams with a length of $28 \mathrm{~m}$, each beam comprising three parts of $10,8,10 \mathrm{~m}$ long, and a diameter of $0.5 \mathrm{~m}$. Parallel to the main beams with a length of $17.5 \mathrm{~m}$ there are 10 lines of secondary beams with a cross-section of semicircular shape and a diameter of $0.25 \mathrm{~m}$. Each secondary beam is comprised of three parts and lies at a distance of $0.2 \mathrm{~m}$ from the lower main beams near the wall and this

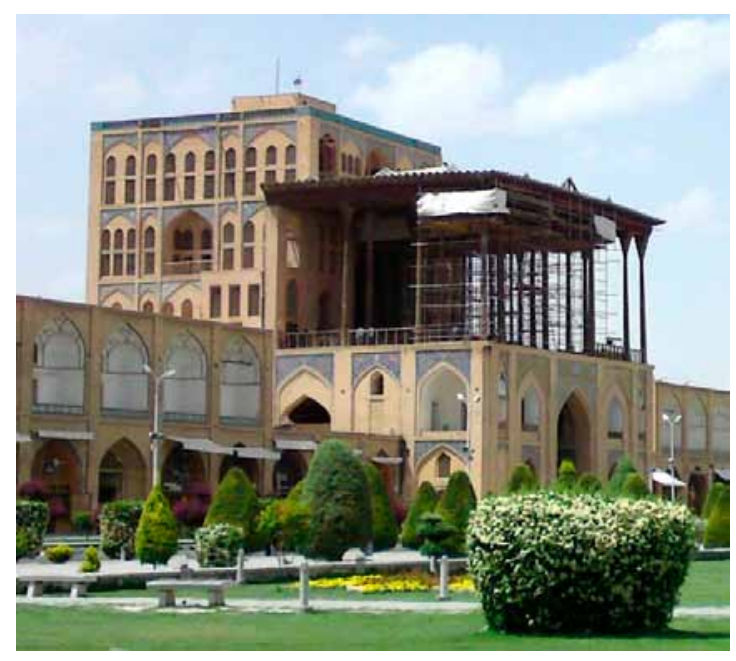

a)

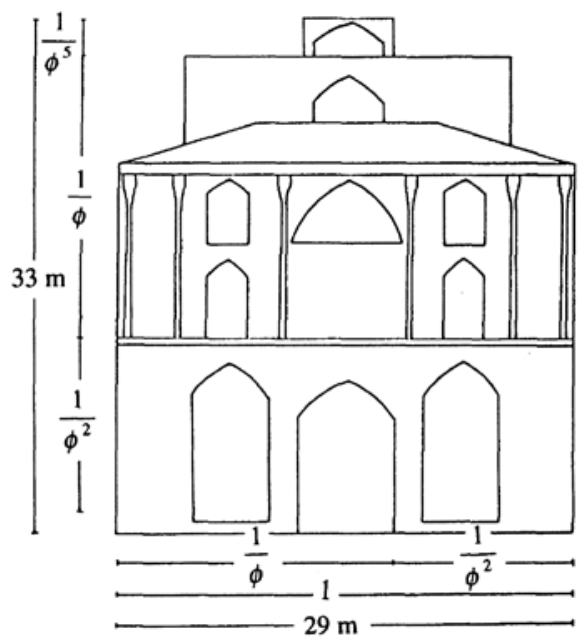

b)

Fig. 26. (a) The building of the Ali Qapu; (b) the use of the Golden Proportion in dimensions, Isfahan, 1597-1668 A.D.

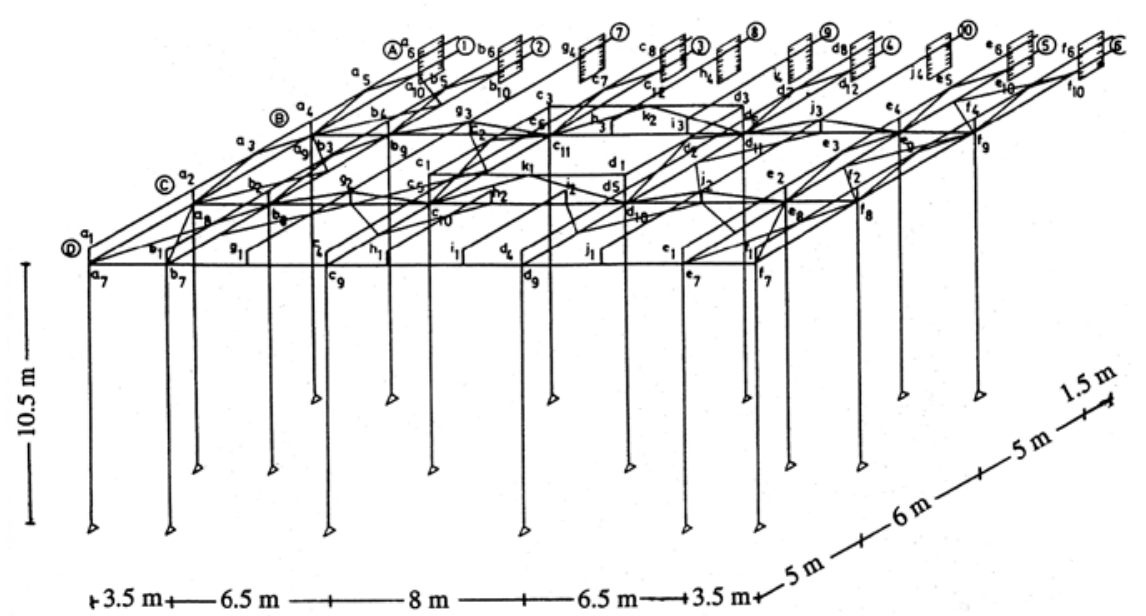

Fig. 27. Wooden structure covering the eastern veranda of the Ali Qapu building, Isfahan, 1597-1668 A.D. 


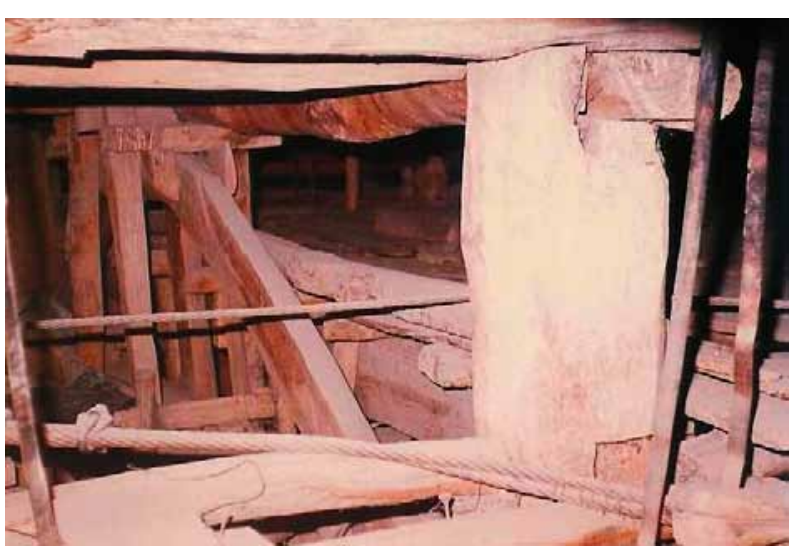

Fig. 28. A wooden truss, Ali Qapu building, Isfahan, 15971668 A.D.

distance gradually diminishes towards the other end. There are $24 \pi$-shape trusses that transfer the load from secondarybeams to the main beams. All around the roof in the outer span there is a horizontal bracing for lateral loading. The rectangular cross-section of the members is $0.1 \times 0.15 \mathrm{~m}$. The members form $\pi$ or $\mathrm{x}$-shape shape trusses with beams. All the elements of the structure are made from the wood of plane-trees. The connections between the elements are made by using iron nails. The roof structure is covered by an upper sloped plate and the lower wooden decorated roof of the veranda making a pyramid-shaped space with a maximum height of about $2 \mathrm{~m}$. The structural analysis of the wooden structure shows that the design of the structure is relatively optimum and structurally a masterpiece according to the modern codes. Aesthetically, the Ali Qapu building shows the application of the Golden Proportion in architecture (Fig. 26). The optimum design is very much related to the Golden Proportion used in the dimensions of the whole building.
The more advanced wooden structure on an immense scale is the Chehel Sutun Palace (1647 A.D.), the 40-Column Palace. 20 columns with a height of $13 \mathrm{~m}$ and a diameter of $0.6 \mathrm{~m}$ at the bottom, diminishing to $0.4 \mathrm{~m}$ at the top, with load bearing walls, sustain the roof that comprises colossal wooden space trusses and beam elements some with a diameter of more than $1 \mathrm{~m}$. This wooden structure contains all the nobility and knowledge of structural design in the architecture of Iran; it is beyond ordinary imagination; it is a superb structure. This building has an important symbolic function. Its 20 columns have a reflection over the pool the building commands, making 40 (chehel) columns (sutuns). Firstly, the reflections correspond to the Platonic Ideas that all the things above have their own reflections below. Secondly, the number chehel in Iranian culture is the symbol of multitude and therefore the Chehel Sutun illustrates that it is through the multiplicity and study of reflections that the metaphysical realm can be perceived.

The most interesting pair of minarets in the world, the Manar Junban, the Shaking Minarets, were built in Isfahan probably in the early eighteenth century A.D. (although the main porch was built in the fourteenth century A.D.). The building consists of two minarets standing over a porch (Fig. 29). The porch is $10 \mathrm{~m}$ high. The height of each minaret is about $7 \mathrm{~m}$ above the roof and therefore $17 \mathrm{~m}$ from the ground level. The lower part of each minaret above the roof has a square shape cross-section that is $1.35 \mathrm{~m}$ square and at $1.7 \mathrm{~m}$ from the roof transfers to a circle with a decreasing diameter of $1.25 \mathrm{~m}$ at the bottom to $1.05 \mathrm{~m}$ at the top. The thickness of the outer shell of the minaret is $0.1 \mathrm{~m}$. A spiral staircase rotates around a circular central column of $0.2 \mathrm{~m}$ in diameter. The minarets are $10 \mathrm{~m}$ apart. The minarets

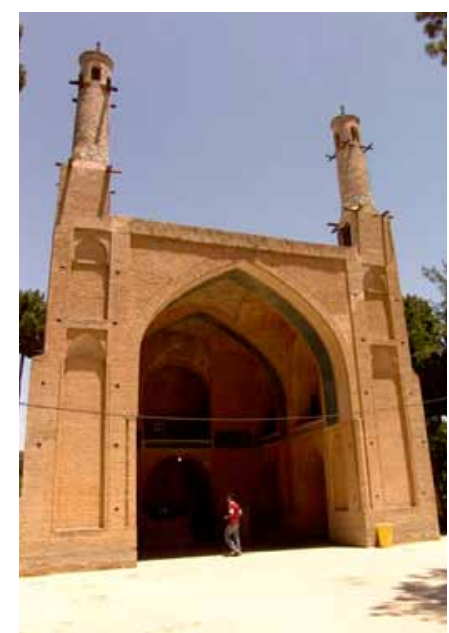

a)

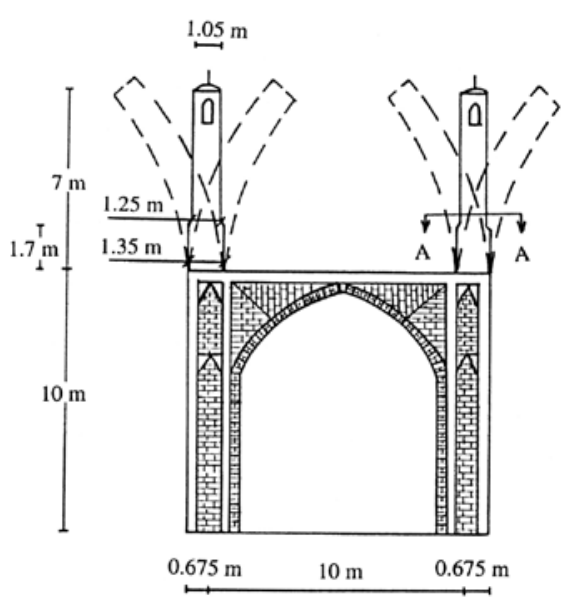

b)

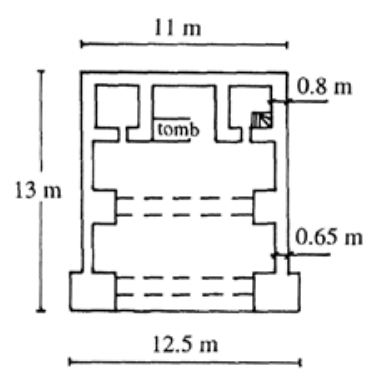

c)

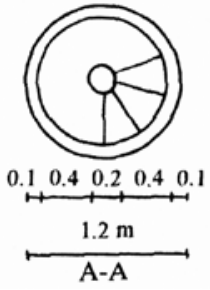

d)

Fig. 29. (a) The Manar Junban, the Shaking Minarets; (b) elevation of the ivan; (c) plan of the building; (d) cross-section of the minaret, Isfahan, probably early eighteenth century A.D. 


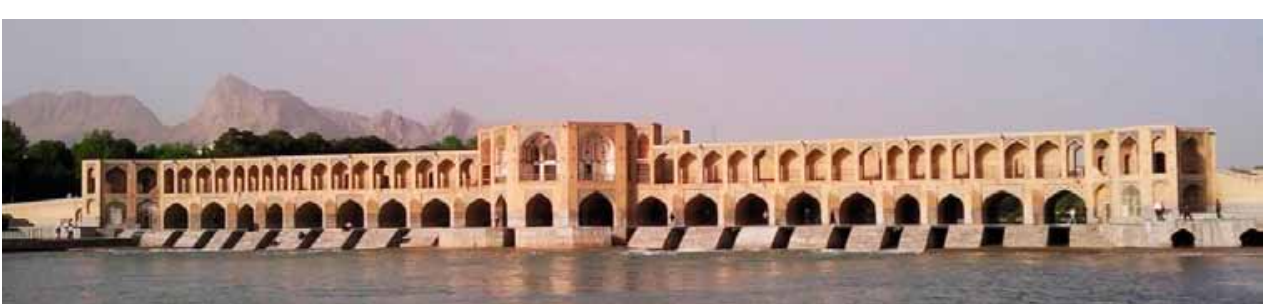

a)

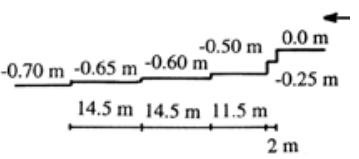

b)

Fig. 30. (a) The Khaju bridge; (b) the bed slope of a canal intake, Isfahan, 1650 A.D.

are made from brick. Spiral stairways lead to the summits that are pierced with open arches. When somebody goes up inside one of the minarets and pushes backwards and forwards vigorously against the wall at the summit, the minaret shakes and the motion is recognisable by the eyes. If the minaret is shaken in the direction of the second minaret, this movement is transmitted to the other minaret. If that shaking is towards other directions, the movement in the second minaret is far less felt but still exists. Three-dimensional finite element analysis of the whole structure shows that by shaking one of the minarets not only does the other minaret shake but also the motion transfers throughout the whole structure. The finite element results are in agreement with results from an ambient vibration test, the measurement of the motion induced in the structure by sensitive accelerometers located at strategic locations throughout the structure. Structurally this building is a wonder of the world. It is the culmination of the theory of structural dynamics and vibration isolation. The discovery of its structural dynamic behaviour can lead to the construction of earthquake resistant buildings.

In the Safavid period two important bridges were built across the Zayandeh-Rud in Isfahan to connect the northern and southern parts of the city via two main avenues, called as the Chahar Bagh (FourGarden) boulevard. These avenues with other streets of the city make a network of roads that according to the theory of town planning and transport system design are still the best and optimum routes for metropolitan transportation and an underground railway. The Allahvardi Khan bridge (1602 A.D.), the Si-u-Seh-Pul or Thirty-Three-Arch bridge, is $360 \mathrm{~m}$ long with a width of over $14 \mathrm{~m}$. This bridge is built on the gravel bed of the river by using pile foundation; a sophisticated method of piling in the water by the use of local traditional materials that can function for several hundreds of years without any settlement.

One of the most beautiful bridges of the world, the Khaju bridge, was built in 1650 A.D. (Fig. 30). It is made of stone and brick, and has two storeys; the upper one is the roadway flanked by two sets of arched enclosures, and the lower one is a set of arches, through which water passes. The bridge is $132 \mathrm{~m}$ long and $12 \mathrm{~m}$ wide. It has 21 arches of stone and brick, each with a span of 4.2 to $5.8 \mathrm{~m}$. The deck of the bridge is $1.2 \mathrm{~m}$ thick. The thickness of piers is 1.6 to $1.9 \mathrm{~m}$. The bridge is pierced by 18 canal intakes, with a bed slope of $1.5 \%$, a depth of 1.95 to $2.6 \mathrm{~m}$, and a width of about $2 \mathrm{~m}$ making a total width of $38 \mathrm{~m}$. The canal intakes are fitted with sluice gates, which can raise the river level $6 \mathrm{~m}$. In times of excessive flow the water passes through the lower tier of the bridge arches, which provides a width of $74 \mathrm{~m}$. The stepped air face of the bridge functions as an energy-dissipating system in times of overflow. It can be shown that the width of the canals varies, harmonically based on the Golden Proportion; aesthetically to make a golden image of the bridge, structurally to make the optimum hydraulic shape for a certain rise of water level, and acoustically to produce a harmonic music of water and stone through air, linked to the echo under the Imam dome and in the Ali Qapu. Here architecture becomes music. This bridge is probably the most perfect hydraulic structure known in Iran.

\section{Strong use of colour (1722-94 A.D.)}

In the Zand period (1722-94 A.D.), Persian architecture used the previous forms. This period was characterised by a strong use of colour. Shiraz became the capital with many fantastic mosques, palaces, citadel walls and a bazaar (Fig. 31).

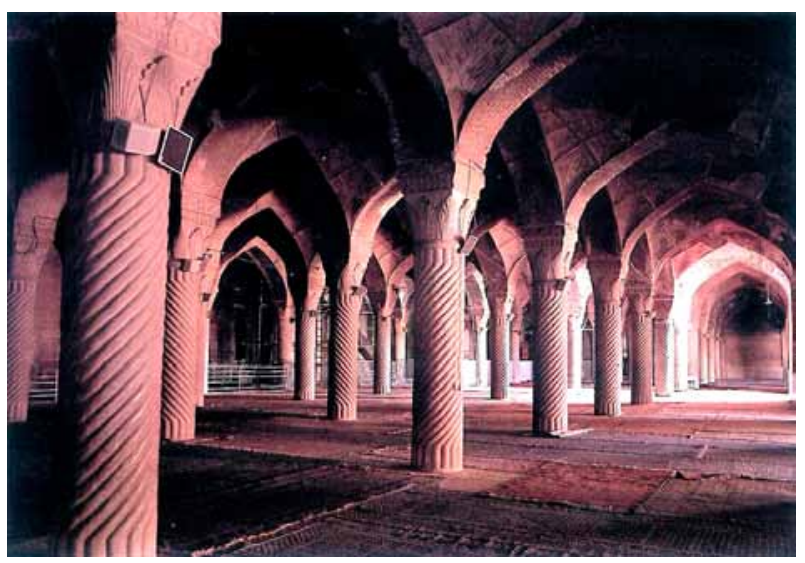

Fig. 31. Vakil mosque, Shiraz, eighteenth century A.D. 


\section{Influence of modern styles (1794 A.D. - present)}

New forms such as very deep courtyards, exaggeratedly onion-formed domes and decorated entrance gates at major cities were introduced in the Qajar period (1794-1925 A.D.). Many palaces, mansions, pavilions and fine houses, such as the Bagh-i-Eram in Shiraz (Fig. 32), were built in this era.

The first influence of western architecture on Persian architecture took place during the Qajar period. European architecture affected decorations, and magnificently decorated ceilings and walls with mirror works were promoted such as in the Gulistan Palace (1870 A.D.) in Tehran (Fig. 33).

Persian architecture was modernised in a new way during the Pahlavi period (1925-1979) and the next era. New construction materials such as steel and concrete became dominant and traditional design of cities changed significantly. New trends brought with them a variety of styles of European and Iranian origin.

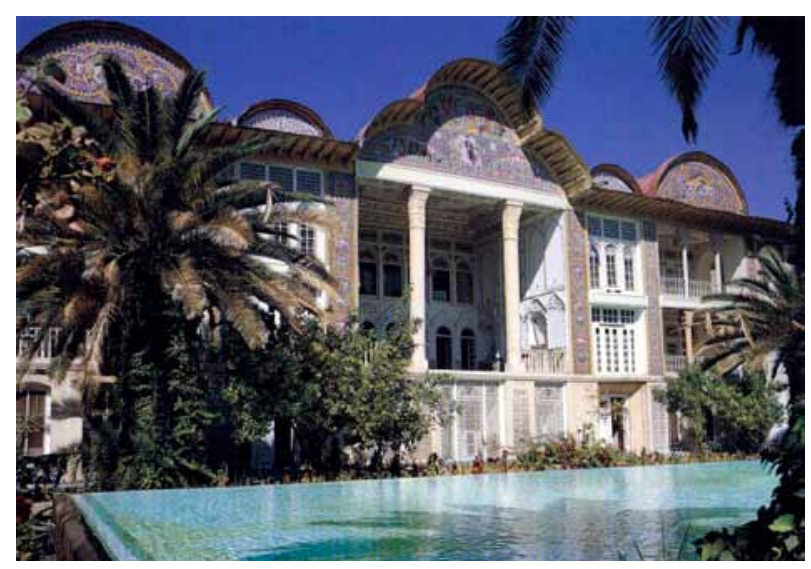

Fig. 32. Bagh-i-Eram, Shiraz, nineteenth century A.D.

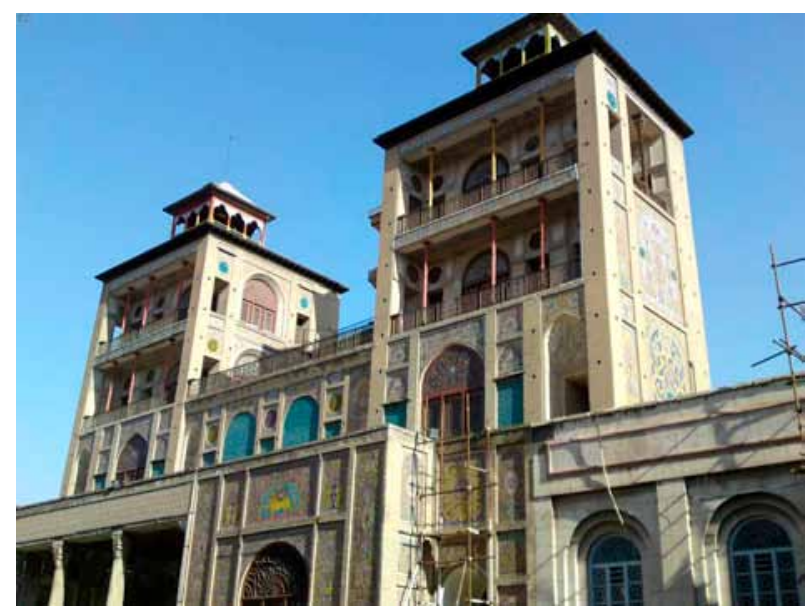

Fig. 33. Gulistan Palace, Tehran, 1870 A.D.

\section{Conclusions}

The architecture of Iran created an enormous number of monuments over a vast area of the world during the centuries. Although it adopted various styles, from hard stone buildings on a square footprint to soft brick structures on a round plan, and developed various types of structures, from earthly underground waterworks to splendid heavenly towers towards the sky, it always maintained its coherence. Persian architecture kept all its virtues and expressed them according to the relevant styles and demands, but within unity. It developed new methods and produced many buildings to stand for many years, as permanence was its idea. One of the greatest achievements of Iranian architecture is the building of the Taj-al-Mulk dome that represents the nobility of the human being. Historical buildings of Iran, like those of other traditional cultures, are a complex of the most advanced features of structural engineering with many unchallenged mysteries whose discovery can indicate the method of right design and correct engineering. The architecture of Iran came into being gradually, established upon subtle foundations that give rise to a more authentic and permanent expression. To-day traditional masons and builders, along with modern architects and civil engineers, make serious attempts to preserve this traditional style that created an imposing record of masterpieces for the benefit of the whole of humanity, namely Persian architecture.

\section{References}

Abruzzese, D.; Como, M.; Lanni, G. 1995. Some results on the strength evaluation of vaulted masonry structures, in Proceedings of the 4th International Conference on Structural Repairs and Maintenance of Historical Buildings (STREMA 95), 22-24 May 1995, Crete, Greece, Southampton: Computational Mechanics Publications (WIT Press), 431-440.

Ackerman, P. 1937. The Takt-i-Tagdis. Bulletin of the Iranian Institute.

Ardalan, N.; Bakhtiar, L. 1973. The sense of unity: the Sufi tradition in Persian architecture. Chicago: The University of Chicago Press.

Bakhtiar, L. 1976. Sufi: expressions of the mystic quest. London: Thames and Hudson.

Barthel, R. 1989. Analysis and structural behaviour of masonry cross vaults, in Proceedings of the 1st International Conference on Structural Repairs and Maintenance of Historical Buildings (STREMA 89), 119-128, 5-7 April 1989, Florence, Italy. Southampton: Computational Mechanics Publications (WIT Press).

Behnia, A. 1987. The Qanat: construction and maintenance. Tehran: University Press Centre. (in Farsi)

Burckhardt, T. 1976. Art of Islam: language and meaning. Translated from French by J. P. Hobson. London: World of Islam Festival. 
Bybordi, M. 1974. Ghanats of Iran: drainage of sloping aquifer, Journal of the Irrigation and Drainage Division, ASCE 100(IR3): 245-253.

Carlton, S. C. 1951. Cave explorations in Iran. Philadelphia: University Museum.

Chassagnoux, A. 1995a. Architecture Voutee Perse: Morphologie et Equilibre des Voutes en Maconnerie sous Charges Statiques et Dynamiques, in Actes du 12eme Congres Francais de Mecanique, 4-8 September 1995, Strasbourg, France. France: Association Universitaire de Mecanique. (in French)

Chassagnoux, A. 1995b. Persian vaulted architecture: morphology and equilibrium of vaults under static and dynamic loads, in Proceedings of the 4th International Conference on Structural Repairs and Maintenance of Historical Buildings (STREMA 95), 22-24 May 1995, Crete, Greece. Southampton: Computational Mechanics Publications (WIT Press).

Chassagnoux, A. 1996a. L'Architecture Voutee Iranienne: PhD Thesis, Universite de Nantes, Nantes. (in French)

Chassagnoux, A. 1996b. Les Coupoles Perses: Comportement sous Charges Statiques et Cynamiques, in Actes du 4eme Colloque National de Genie Parasismique, 10-12 April 1996, Saint-Remy-les-Chevreuses, France. (in French)

Chassagnoux, A. 1996c. Morphology and equilibrium of Persian domes under static and dynamic loads, in Proceedings of the 3rd European Conference on Structural Dynamics (Eurodyn'96), 5-8 June 1996, Florence, Italy.

Christensen, A. 1944. Iran sous les Sasanids. Copenhagen.

Dieulafoy, C. 1883. Revue d'Architecture et des Travuax Publiques. Paris.

Farshad, M. 1977. On the shape of momentless tensionless masonry domes, Building and Environment 12: 81-85. http:// dx.doi.org/10.1016/0360-1323(77)90036-1

Farshad, M. 1978. History of engineering in Iran. Shiraz: Shiraz University Press. (in Farsi)

Farshad, M.; D. Isfahanian. 1978. Investigation of an antique seal obtained from the excavations in Susa. Shiraz: Historical Studies. (in Farsi)

Forbes, R. J. 1964. Studies in ancient Technology. $2^{\text {nd }}$ ed. Leiden. Ghirshman, R. 1951. L'Iran des Origines a l'Islam. Paris: Payot. Godard, A. 1946. Athar-e-Iran. Paris.

Godard, A. 1962. L'Art de l'Iran. Paris: Arthaud.

Grant, M. 1971. Ancient History Atlas. London: Tinling.

Hejazi, M. 1987. Stability and strength of the wooden columnar building of the Ali Qapu: BSc dissertation, Isfahan University of Technology, Isfahan. (in Farsi)

Hejazi, M. 1990. Analysis of Iranian domes and research on traditional art: MSc dissertation, Isfahan University of Technology, Isfahan. (in Farsi)

Hejazi, M. 1997. historical buildings of Iran: their architecture and structure. Southampton: Computational Mechanics Publications (WIT Press).

Hejazi, M. 2003. Seismic vulnerability of Iranian historical domes, in Proceedings of the 4th International Conference on Earthquake Resistant Engineering Structures, 157-165, 22-24 September 2003, Ancona, Italy. Southampton: WIT Press.

Hejazi, M. 2005a. Geometry in nature and Persian architecture, Building and Environment 40: 1413-1427. http://dx.doi.org/10.1016/j.buildenv.2004.11.007
Hejazi, M. 2005b. Maintenance comments on a Persian historical wooden building, in Proceedings of the 9th International Congress on Structural Studies, Repairs and Maintenance of Heritage Architecture (STREMAH 2005), 22-24 June 2005, Malta. Southampton: WIT Press.

Hejazi, M. 2006. Structural analysis of the wooden structure of the historical building of Ali Qapu, Journal of Structural Engineering, ASCE 132(11): 1801-1805. http://dx.doi. org/10.1061/(ASCE)0733-9445(2006)132:11(1801)

Hejazi, M.; Moayedian, S. M.; Daei, M. 2015. Structural analysis of Persian historical brick masonry minarets, Journal of Performance of Constructed Facilities, ASCE 30(1): 1-15. http://dx.doi.org/10.1061/(asce)cf.1943-5509.0000746

Hejazi, M.; Khallaghi, F. M. 1994. Historical development of the art and science of irrigation, bridge and dam construction in the islamic world (in Farsi), in Proceedings of the 1st International Congress for the Advancement of Science and Technology in the Islamic World, Tehran.

Hejazi, M.; Mirghaderi, R. 1988. Stability and strength of the wooden columnar building of the Ali Qapu. Technical Report, No. 108. Isfahan: Isfahan University of Technology. (in Farsi)

Hejazi, M.; Mirghaderi, R. 1990. Columnar building of the Ali Qapu, in Proceedings of the 3rd Iranian Congress of Civil Engineering, 12-14 May 1990, Shiraz. (in Farsi)

Hejazi, M.; Mirghaderi, M. 1991. Earthquake effects on Iranian traditional domes, in Proceedings of the 1st International Conference of Seismology and Earthquake Engineering, 27-29 May 1991, Tehran. (in Farsi)

Hejazi, M.; Mirghaderi, R. 2003. Analysis and design control of the wooden columnar structure of the Ali Qapu historical building, International Journal of Engineering Sciences 14(2): 77-91. (in Farsi)

Hejazi, M.; Zargar, A.; Zamanifard, A. 2002. A view on dome restoration in Iran, Asar 33-34: 227-277. (in Farsi)

Herodotus. 1996. The Histories. Translated from Greek by De A. Selincourt, revised by J. Marincola. London: Penguin.

Hodges, H. 1970. Technology in the Ancient World. London: Penguin.

Ibn-al-Balkhi. 1912. Description of the province of Fars in Persia. London: Royal Asiatic Society Monographs, XIV.

Matthews, J. 1981. The Grail: quest for the eternal. London: Thames and Hudson.

Nasr, S. H. 1976. Islamic science: an illustrated study. London: World of Islam Festival.

Nasr, S. H. 1987. Islamic art and spirituality. Ipswich: Golgonooza.

Poems for the Devan of Hafiz. 1897. Translated from the Persian by G. L. Bell. London: W. Heinemann.

Pope, A. U. 1965. Persian architecture. London: Thames and Hudson.

Pope, A. U.; Ackerman, P. 1938. A survey of Persian art: from prehistoric times to the present. 6 vols. London and New York: Oxford University Press.

The Haft Paikar. 1924. Translated from the Persian by C. E. Wilson. London: Probsthain.

The Mathnawi of Jalal U'ddin Rumi. 1937-1940. Translated from the Persian by R. A. Nicholson. London: Luzac.

Von der Ostan, H. H.; Naumann, R. 1961. Takht-i-Suleiman, Vorlaufiger Bericht uber die Ausgrabungen 1959, 1. Berlin: Teheraner Forschungen. 
Wullf, H. 1966. The traditional crafts of Persia. Cambridge: The MIT Press.

Zahraei, M. 1989. A study of the structural systems of Iranian arches and domes: MSc dissertation, Sharif University of Technology, Tehran. (in Farsi)

Zahraei, M.; Akbar, H. 1990. A study of the structural systems of Iranian arches and domes, in Proceedings of the 3rd Iranian Congress of Civil Engineering, 12-14 May 1990, Shiraz. (in Farsi)

Zander, G. 1968. Travaux de restauration de monuments historiques en Iran. Rome: Istituto Italiano per il Medio ed Estremo Oriente.

\section{MEHRDAD HEJAZI}

Assoc. Prof., Department of Civil Engineering, Faculty of Engineering, University of Isfahan, Hezar Jarib Street,

Isfahan 8174573441, Iran

Email:m.hejazi@eng.ui.ac.ir

Research interests: traditional and historical structures, restoration of architectural heritage buildings, modern structures, the finite element method. Publications: four books on Persian architectural heritage, 27 journal papers, 70 conference papers. Projects: restoration of world heritage buildings in Iran. Membership: ICOMOS/ISCARSAH.

\section{BINA HEJAZI}

MArch in Architectural Engineering, Department of Architecture, Isfahan (Khorasgan) Branch, Islamic Azad University, Isfahan, Iran

Email: bina.hejazi@yahoo.com

Research interests: vernacular and modern architecture, climatic architectural design. Publications: four journal papers, seven conference papers.

\section{SABA HEJAZI}

BArch in Architectural Engineering, Department of Architecture and Urbanism, Art University of Isfahan, Hakim Nezami Street, Isfahan, Iran

Email:saba.hejazi@yahoo.com

Research interests: vernacular and modern architecture. Publications: two journal papers. 